\title{
Source attribution and interannual variability of Arctic pollution in spring constrained by aircraft (ARCTAS, ARCPAC) and satellite (AIRS) observations of carbon monoxide
}

\author{
J. A. Fisher ${ }^{1}$, D. J. Jacob ${ }^{1}$, M. T. Purdy ${ }^{1, *}$, M. Kopacz ${ }^{1, * *}$, P. Le Sager ${ }^{1}$, C. Carouge ${ }^{1}$, C. D. Holmes ${ }^{1}$, R. M. Yantosca ${ }^{1}$, \\ R. L.Batchelor ${ }^{2}$, K. Strong ${ }^{2}$, G. S. Diskin ${ }^{3}$, H. E. Fuelberg ${ }^{4}$, J. S. Holloway ${ }^{5,6}$, E. J. Hyer ${ }^{7}$, W. W. McMillan ${ }^{8,9}$, \\ J. Warner ${ }^{9}$, D. G. Streets ${ }^{10}$, Q. Zhang ${ }^{10,11}$, Y. Wang ${ }^{12}$, and S. Wu ${ }^{13}$ \\ ${ }^{1}$ Department of Earth and Planetary Sciences and School of Engineering and Applied Sciences, Harvard University, \\ Cambridge, Massachusetts, USA \\ ${ }^{2}$ Department of Physics, University of Toronto, Toronto, Ontario, Canada \\ ${ }^{3}$ NASA Langley Research Center, Hampton, Virginia, USA \\ ${ }^{4}$ Department of Meteorology, Florida State University, Tallahassee, Florida, USA \\ ${ }^{5}$ Cooperative Institute for Research in Environmental Science, University of Colorado, Boulder, Colorado, USA \\ ${ }^{6}$ Chemical Sciences Division, NOAA Earth System Research Laboratory, Boulder, Colorado, USA \\ ${ }^{7}$ UCAR Visiting Scientist Program, Naval Research Laboratory, Monterey, California, USA \\ ${ }^{8}$ Department of Physics, University of Maryland, Baltimore County, Baltimore, Maryland, USA \\ ${ }^{9}$ Joint Center for Earth Systems Technology, University of Maryland, Baltimore, Maryland, USA \\ ${ }^{10}$ Decision and Information Sciences Division, Argonne National Laboratory, Argonne, Illinois, USA \\ ${ }^{11}$ Center for Earth System Science, Tsinghua University, Beijing, China \\ ${ }^{12}$ Department of Environmental Science and Engineering, Tsinghua University, Beijing, China \\ ${ }^{13}$ Department of Geological and Mining Engineering and Sciences and Department of Civil and Environmental Engineering, \\ Michigan Technological University, Houghton, Michigan, USA \\ * now at: Risk Management Solutions, Hackensack, New Jersey, USA \\ ** now at: Woodrow Wilson School of Public and International Affairs, Princeton University, Princeton, New Jersey, USA
}

Received: 31 August 2009 - Published in Atmos. Chem. Phys. Discuss.: 14 September 2009

Revised: 15 January 2010 - Accepted: 19 January 2010 - Published: 1 February 2010

\begin{abstract}
We use aircraft observations of carbon monoxide (CO) from the NASA ARCTAS and NOAA ARCPAC campaigns in April 2008 together with multiyear (20032008) CO satellite data from the AIRS instrument and a global chemical transport model (GEOS-Chem) to better understand the sources, transport, and interannual variability of pollution in the Arctic in spring. Model simulation of the aircraft data gives best estimates of $\mathrm{CO}$ emissions in April 2008 of $26 \mathrm{Tg} \mathrm{month}^{-1}$ for Asian anthropogenic, 9.4 for European anthropogenic, 4.1 for North American anthropogenic, 15 for Russian biomass burning (anomalously large that year), and 23 for Southeast Asian biomass burning. We find that Asian anthropogenic emissions are the dominant source of Arctic CO pollution everywhere except in surface air where European anthropogenic emissions are of similar
\end{abstract}

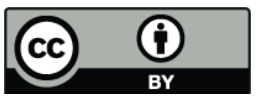

Correspondence to: J. A. Fisher (jafisher@fas.harvard.edu) importance. Russian biomass burning makes little contribution to mean $\mathrm{CO}$ (reflecting the long $\mathrm{CO}$ lifetime) but makes a large contribution to $\mathrm{CO}$ variability in the form of combustion plumes. Analysis of two pollution events sampled by the aircraft demonstrates that AIRS can successfully observe pollution transport to the Arctic in the mid-troposphere. The 2003-2008 record of CO from AIRS shows that interannual variability averaged over the Arctic cap is very small. AIRS CO columns over Alaska are highly correlated with the Ocean Niño Index, suggesting a link between El Niño and Asian pollution transport to the Arctic. AIRS shows lowerthan-average CO columns over Alaska during April 2008, despite the Russian fires, due to a weakened Aleutian Low hindering transport from Asia and associated with the moderate 2007-2008 La Niña. This suggests that Asian pollution influence over the Arctic may be particularly large under strong El Niño conditions.

Published by Copernicus Publications on behalf of the European Geosciences Union. 


\section{Introduction}

The Arctic is a major receptor for mid-latitudes pollution (Shaw, 1995; Quinn et al., 2007). Radiative forcing by pollutants in the Arctic including ozone, aerosols, and black carbon deposited on snow could make a major contribution to regional and global warming (Koch and Hansen, 2005; Shindell et al., 2006a; McConnell et al., 2007; Quinn et al., 2008; Shindell and Faluvegi, 2009). Several studies have identified pollution transport pathways to the Arctic on the basis of model simulations and meteorological analyses (Eckhardt et al., 2003; Klonecki et al., 2003; Koch and Hansen, 2005; Stohl, 2006; Shindell et al., 2008), but our ability to verify these pathways through chemical observations has been limited. Polar-orbiting satellites offer unique platforms for this purpose. We present here an analysis of the sources and transport of Arctic pollution in spring using the GEOS-Chem chemical transport model (CTM) to interpret satellite observations of carbon monoxide (CO) from the Atmospheric InfraRed Sounder (AIRS) together with aircraft measurements from the NASA ARCTAS (Arctic Research of the Composition of the Troposphere from Aircraft and Satellites) and NOAA ARCPAC (Aerosol, Radiation, and Cloud Processes affecting Arctic Climate) campaigns.

Despite 50 years of observations of Arctic pollution, there remains considerable uncertainty concerning the sources. Surface-based studies conducted in the 1970s and 1980s focused on anthropogenic pollution transported from Eastern Europe and Siberia (Carlson, 1981; Rahn, 1981; Raatz and Shaw, 1984; Barrie, 1986). Wintertime influence from these regions is facilitated by cold surface temperatures and stable conditions, enabling low-altitude isentropic transport to the Arctic (Barrie, 1986; Klonecki et al., 2003; Stohl, 2006; Law and Stohl, 2007). Pollutants from Asia and North America, emitted at lower latitudes and therefore warmer temperatures, were thought to be inhibited from entering the Arctic by the "polar dome", an isentropic transport barrier.

Recent research has called into question the predominance of Europe as the main source of Arctic pollution. Modeling studies have shown that while near-surface pollution may still be dominated by European sources, transport from Asia and North America is possible at higher altitudes, facilitated by lofting of pollutants by warm conveyor belts (WCBs) (Koch and Hansen, 2005; Stohl, 2006; Shindell et al., 2008). Furthermore, with the collapse of the Soviet Union, strict emission controls in the European Union, and the rapid industrialization of China and Southeast Asia, the global distribution of emissions has changed dramatically over the past 20 years. Several studies show increasing contributions from Asia but disagree quantitatively on the importance of this source for overall Arctic pollution (Koch and Hansen, 2005; Stohl, 2006; Shindell et al., 2008). As interest in Arctic pollution has broadened from air quality to climate impacts, there is a pressing need to understand pollution sources not only at the surface but throughout the troposphere.
Biomass burning has recently been suggested as an additional important source of Arctic pollution. Black carbon records in Greenland ice cores show large concentrations attributable to fire emissions dating back to the pre-industrial era (McConnell et al., 2007), and more recent measurements in snow suggest that biomass burning accounts for more than $90 \%$ of the black carbon deposited in the Arctic in spring (Hegg et al., 2009). Fires in Eastern Europe and Russia have been shown to cause substantial increases in the atmospheric loading of pollutants including CO, ozone, and aerosols measured at surface sites in the European Arctic (Stohl et al., 2007). Early analysis of the ARCPAC aircraft data identified a substantial contribution from Russian forest fires and central Asian agricultural burning to atmospheric pollution over Alaska (Warneke et al., 2008).

$\mathrm{CO}$ is emitted by incomplete combustion, and we use it here as a tracer of pollution. Its atmospheric lifetime against oxidation by the hydroxyl radical $(\mathrm{OH})$ is on average two months, long enough to track transport on intercontinental scales but short enough to show well-defined concentration gradients (Staudt et al., 2001; Heald et al., 2003a; Liu et al., 2003; Liang et al., 2004; Turquety et al., 2008; Yashiro et al., 2009). In a recent intercomparison of 11 CTMs, simulated $\mathrm{CO}$ concentrations disagreed by a factor of $2-3$ at all altitudes in the Arctic due to model differences in emissions, transport, and $\mathrm{OH}$ concentrations (Shindell et al., 2008). There is a need to better understand $\mathrm{CO}$ sources and transport to the Arctic as an indicator of pollution influence.

Satellite observations present a unique perspective to address these issues. $\mathrm{CO}$ is readily detectable from space at infrared (IR) wavelengths, and data are available from a number of satellite instruments, including MOPITT, AIRS, TES, SCIAMACHY, and IASI. AIRS is particularly promising for studying pollution transport to the Arctic because of its high spatial density (up to 70\% global coverage daily) (McMillan et al., 2005), sensitivity at high latitudes, cloud-clearing capabilities (Susskind et al., 2003), and multi-year record (continuous observations since mid-2002). It is a nadirviewing thermal IR sounder onboard NASA's polar-orbiting Aqua satellite and retrieves CO at $4.7 \mu \mathrm{m}$ (McMillan et al., 2009). As with all thermal IR sounders, the sensitivity to $\mathrm{CO}$ is strongest in the mid-troposphere and generally weak in the boundary layer, with little vertical resolution (Warner et al., 2007; McMillan et al., 2008); however, in some instances, AIRS can see $\mathrm{CO}$ enhancements down to the top of the boundary layer (McMillan et al., 2009, 2010). Validation of AIRS CO retrievals in the northern hemisphere indicates AIRS is biased approximately $10 \%$ high from 300 $900 \mathrm{mb}$, with little quantitative sensitivity to the boundary layer (McMillan et al., 2009). AIRS CO observations have been shown to successfully track the transpacific transport of Asian pollution to North America (Zhang et al., 2008) and the transatlantic transport of North American wildfire emissions to Europe (McMillan et al., 2008). Total column AIRS $\mathrm{CO}$ retrievals have been validated at three high-latitude sites 
(Yurganov et al., 2009), but application to Arctic pollution transport had not previously been tested.

Aircraft data from the ARCTAS and ARCPAC campaigns based in Alaska in April 2008 can help evaluate the utility of the AIRS data for observing long-range transport to the Arctic. The in situ measurements provide highly accurate information on the structure of Arctic $\mathrm{CO}$ distributions, allowing an independent test of the AIRS CO data. The aircraft observations can further provide quantitative constraints on sources of $\mathrm{CO}$ in the Arctic.

We examine here the influence of different source types (fuel combustion, biomass burning) and mid-latitude source regions on Arctic pollution in spring, using the GEOS-Chem CTM as a platform for intercomparing the aircraft and satellite datasets. We first use the aircraft observations to constrain the CO sources in the CTM and subsequently use the CTM to quantify the source contributions to Arctic CO pollution. The aircraft observations together with the CTM are used to test the ability of AIRS to observe high-latitude pollution transport. We then use AIRS observations to investigate the interannual variability of $\mathrm{CO}$ transport to the Arctic.

\section{Model description}

We use the GEOS-Chem CTM version 8-01-04 (http://acmg. seas.harvard.edu/geos/index.html) driven by GEOS-5 assimilated meteorology from the NASA Global Modeling and Assimilation Office (GMAO) Goddard Earth Observing System (GEOS). The native resolution of GEOS-5 is $0.5^{\circ} \times 0.667^{\circ}$ with 72 vertical levels; we regrid to $2^{\circ} \times 2.5^{\circ}$ for input to GEOS-Chem. The GEOS-Chem simulation of CO has previously been used to track intercontinental transport of pollution (Li et al., 2002; Heald et al., 2003a; Liu et al., 2003; Duncan and Bey, 2004; Jaffe et al., 2004; Liang et al., 2004; Zhang et al., 2008) and has been extensively compared to in situ and satellite observations (Jaeglé et al., 2003; Kiley et al., 2003; Liu et al., 2003; Heald et al., 2006; Koike et al., 2006; Duncan et al., 2007; Duncan and Logan, 2008; Hudman et al., 2008).

We simulate April 2008 preceded by a 10-month spin-up. Anthropogenic (fossil fuel and biofuel) sources of $\mathrm{CO}$ are simulated using state-of-the-science regional emission inventories as described in Table 1. Emissions from sources not accounted for in the regional inventories are taken from the EDGAR 3.2 FT2000 global emissions inventory for 2000 (Olivier et al., 1999; Olivier and Berdowski, 2001). Biomass burning emissions are from the Fire Locating and Monitoring of Burning Emissions (FLAMBE) inventory (Reid et al., 2009), which provides carbon emissions at $1^{\circ} \times 1^{\circ}$ spatial resolution and hourly temporal resolution based on both MODIS and GOES satellite fire counts (Naval Research Laboratory, http://www.nrlmry.navy.mil/flambe/). CO emissions are subsequently calculated using emission factors from Andreae and Merlet (2001). All emissions are injected into the local planetary boundary layer as defined from the GEOS5 data. While this could cause an underestimate of vertical transport of $\mathrm{CO}$ from the most energetic fires, recent work has shown that direct free tropospheric injection of biomass burning plumes is infrequent (Labonne et al., 2007; Kahn et al., 2008; Val Martin et al., 2009).

Additional sources of $\mathrm{CO}$ in our simulation include oxidation of methane $\left(\mathrm{CH}_{4}\right)$ and non-methane volatile organic compounds (NMVOCs). Methane is specified using latitudinally-resolved observations from the NOAA/ESRL/GMD network (Dlugokencky et al., 2008). A yield of one $\mathrm{CO}$ molecule per oxidized $\mathrm{CH}_{4}$ molecule is assumed. Oxidation of anthropogenic and biomass burning NMVOCs is simulated by increasing direct $\mathrm{CO}$ emissions from these sources by $19 \%$ and $11 \%$ respectively (Duncan et al., 2007). Biogenic NMVOC sources in the model include isoprene, monoterpenes, methanol, and acetone. All NMVOCs are assumed to oxidize immediately to $\mathrm{CO}$ with yields given by Duncan et al. (2007). These indirect emissions are not included in the regional $\mathrm{CO}$ emission totals given later in the paper.

We use a linear CO simulation (Duncan et al., 2007) with monthly mean archived $\mathrm{OH}$ concentrations from a previous GEOS-Chem full-chemistry simulation (Park et al., 2004). The annual global mean $\mathrm{OH}$ concentration in our simulation is $10.8 \times 10^{5}$ molecules $\mathrm{cm}^{-3}$. This is close to the 25model mean of $11.1 \pm 1.7 \times 10^{5}$ molecules $\mathrm{cm}^{-3}$ reported in the Shindell et al. (2006a) CTM intercomparison and higher than the $9.4 \times 10^{5}$ molecules $\mathrm{cm}^{-3}$ reported for GEOS-Chem in that comparison. For source attribution, the linearity of the model permits us to include tagged $\mathrm{CO}$ tracers from individual sources that are consistent with the overall CO simulation.

Model CO emissions for April 2008 are shown in Fig. 1 and summarized in Table 1. The highest emissions (red hotspots in Fig. 1) are due to biomass burning, with particularly intense fire activity over Southeast Asia (Vietnam and Myanmar) and over southern Russia near the Russia-China border. The FLAMBE inventory includes $51 \mathrm{Tg}^{\text {month }}{ }^{-1}$ of $\mathrm{CO}$ emissions from Southeast Asian fires in April. This value is more than twice that reported in previous studies (e.g., $18 \mathrm{Tg} \mathrm{month}^{-1}$ for April in Duncan et al. (2003), and $23 \mathrm{Tg}$ month $^{-1}$ in Heald et al. (2003b)) and in other inventories (e.g., $6 \mathrm{Tg}$ month $^{-1}$ in GFED2). Satellite fire counts for the region show no significant increases in burning in 2008 relative to other years (Acker and Leptoukh, 2007). The FLAMBE emissions inventory is probably too high, as discussed further below. Russian fires during April 2008 were much more intense than usual at that time of year because of lower-than-normal snow cover during the previous winter (Warneke et al., 2008). Figure 2 shows a timeseries of 2001-2008 monthly fire counts from the MODIS instrument aboard the Terra satellite. Satellite fire counts over Russia in April 2008 were 2.5 times the April average and higher than for any month of the record except May 2003. 
Table 1. Global CO sources for April 2008 used in GEOS-Chem simulations.

\begin{tabular}{|c|c|c|}
\hline \multirow[t]{2}{*}{ Source } & \multicolumn{2}{|c|}{ CO Emission $\left(\right.$ Tgmonth $\left.^{-1}\right)$} \\
\hline & Prior Simulation $^{\mathrm{a}}$ & Optimized Simulation $^{b}$ \\
\hline Anthropogenic ${ }^{\mathrm{c}}$ & 51 & 59 \\
\hline North America $^{\mathrm{d}}\left(172.5-17.5^{\circ} \mathrm{W}, 24-88^{\circ} \mathrm{N}\right)$ & 4.2 & 4.2 \\
\hline Europe $^{\mathrm{e}}\left(17.5^{\circ} \mathrm{W}-60^{\circ} \mathrm{E}, 33-88^{\circ} \mathrm{N}\right)$ & 6.2 & 9.1 \\
\hline $\operatorname{Siberia}^{\mathrm{f}}\left(60-172.5^{\circ} \mathrm{E}, 50-88^{\circ} \mathrm{N}\right)$ & 0.4 & 0.4 \\
\hline $\operatorname{Asia}^{\mathrm{g}}\left(60-152.5^{\circ} \mathrm{E}, 0-50^{\circ} \mathrm{N}\right)$ & 22 & 26 \\
\hline Rest of the world $\mathrm{f}^{\mathrm{f}}$ & 9.9 & 9.9 \\
\hline Secondary production from NMVOC oxidation ${ }^{\mathrm{h}}$ & 8.1 & 9.4 \\
\hline Biomass Burning ${ }^{\mathrm{i}}$ & 104 & 50 \\
\hline North America $\left(172.5-17.5^{\circ} \mathrm{W}, 24-88^{\circ} \mathrm{N}\right)$ & 0.3 & 0.3 \\
\hline Europe $\left(17.5^{\circ} \mathrm{W}-60^{\circ} \mathrm{E}, 33-88^{\circ} \mathrm{N}\right)$ & 2.0 & 2.0 \\
\hline Russia/Kazakhstan $\left(60-152.5^{\circ} \mathrm{E}, 33-60^{\circ} \mathrm{N}\right)$ & 29 & 9.3 \\
\hline Southeast Asia $\left(60-152.5^{\circ} \mathrm{E}, 0-33^{\circ} \mathrm{N}\right)$ & 51 & 21 \\
\hline Rest of the world & 12 & 12 \\
\hline Secondary production from NMVOC oxidation ${ }^{\mathrm{h}}$ & 10 & 4.9 \\
\hline Biogenic $^{j}$ & 29 & 29 \\
\hline Methane & 71 & 71 \\
\hline TOTAL & 255 & 209 \\
\hline
\end{tabular}

${ }^{a}$ Monthly source totals from the original GEOS-Chem emission inventories.

${ }^{b}$ Changes from the prior simulation reflect source corrections based on the ARCTAS and ARCPAC aircraft observations (Table 2).

${ }^{c}$ Anthropogenic sources include fossil fuel and biofuel emissions.

${ }^{\mathrm{d}}$ North America includes Canada, the United States, and Mexico. Primary emissions over the US are derived by decreasing the US Environmental Protection Agency National Emission Inventory (EPA-NEI99, http://www.epa.gov/ttnchie1/net/1999inventory.html) CO emissions by 60\%, following Hudman et al. (2008). Canadian emissions are from the Criteria Air Contaminants (CAC) inventory (Environment Canada, http://www.ec.gc.ca/pdb/cac/cac_home_e.cfm) and Mexican emissions are from the Big Bend Regional Aerosol and Visibility Observational Study Emissions Inventory (BRAVO) (Kuhns et al., 2005).

e European anthropogenic emissions are from the Cooperative Programme for Monitoring and Evaluation of the Long-range Transmission of Air Pollutants in Europe (EMEP) inventory (Vestreng and Klein, 2002).

${ }^{\mathrm{f}}$ Siberian and "rest of the world" anthropogenic emissions are from the EDGAR 3.2 FT2000 inventory (Olivier et al., 1999; Olivier and Berdowski, 2001).

g Asian emissions are derived from the NASA INTEX-B inventory for 2006 (Zhang et al., 2009) with seasonality based on monthly activity levels of $\mathrm{NO}_{\mathrm{x}}$ emissions (Zhang et al., 2007).

h Secondary CO sources are computed by increasing direct CO emissions by $11 \%$ for biomass burning emissions and by $19 \%$ for anthropogenic emissions (Duncan et al., 2007). Over the US, anthropogenic CO is increased by 39\% rather than 19\% to account for the improved CO source estimate from Hudman et al. (2008).

${ }^{\mathrm{i}}$ Biomass burning CO emissions are from the FLAMBE inventory (Reid et al., 2009) and are computed as described in the text.

$\mathrm{j}$ The source from the oxidation of biogenic NMVOCs is computed following Duncan et al. (2007) and includes acetone and methanol as well as the Model of Emissions of Gases and Aerosols from Nature (MEGAN) inventory for isoprene and monoterpenes (Guenther et al., 2006).

To compare GEOS-Chem and in situ aircraft $\mathrm{CO}$, the model is sampled along the flight track at the same time and location as the observations. The aircraft data are averaged over the GEOS-Chem grid and time-step. For comparison with AIRS, GEOS-Chem is sampled at the AIRS overpass locations and averaged over a 3-h window centered at the 13:30 local overpass time. AIRS retrieves $\mathrm{CO}$ profiles on nine trapezoidal pressure layers sampled from the 100 AIRS pres- sure levels. GEOS-Chem model profiles are convolved to AIRS retrieval space using the convolution equation (Olsen et al., 2007; McMillan et al., 2009) and summed over the 100 pressure levels to compute the modeled total CO column:

$\hat{y}_{m}=\sum_{i} z_{a, i} \exp \left(\mathbf{F A F} \mathbf{F}^{\prime} \cdot \ln \frac{z_{m, i}}{z_{a, i}}\right)$,

where $\hat{y}_{m}$ is the convolved model column, $z_{m, i}$ is the original 
model profile of partial columns interpolated onto the 100 AIRS pressure levels $i, z_{a, i}$ is the AIRS retrieval a priori profile of partial columns, $\mathbf{F}$ is a $100 \times 9$ matrix that defines the nine vertical trapezoidal layers on which AIRS CO is retrieved, $\mathbf{F}^{\prime}$ is its pseudo-inverse, and $\mathbf{A}$ is a $9 \times 9$ averaging kernel matrix in the trapezoidal space. The degrees of freedom (DOF) for signal, measuring the number of pieces of information in the vertical profile, are generally less than 1.5 (Kopacz et al., 2010), so we use total column CO rather than profiles. The column sensitivity as indicated by the averaging kernels is low in the boundary layer and has a broad maximum at 300-600 hPa (Warner et al., 2007; McMillan et al., 2009; McMillan et al., 2010).

In this study we use version 5 AIRS CO retrievals (available from http://disc.sci.gsfc.nasa.gov/AIRS/data-holdings/ by-data-product/) and, following the recommendations in McMillan et al. (2009), include only daytime AIRS observations with DOF for signal greater than 0.5 retrieved over surfaces with temperature above $250 \mathrm{~K}$. These thresholds eliminate on average $20 \%$ of the available daytime observations globally and 25\% in the Arctic in April.

\section{CO observations and constraints on sources}

Jacob et al. (2009) give a general description of the NASA ARCTAS campaign. A major goal was to observe longrange transport of pollution to the Arctic using a DC-8 aircraft based in Fairbanks, Alaska from 1 to 19 April 2008. CO measurements were made using the Differential Absorption of CO Measurement (DACOM) instrument at a frequency of $1 \mathrm{~Hz}$ and accuracy of $2 \%$ (Sachse et al., 1987). The NOAA ARCPAC campaign (Warneke et al., 2008) took place concurrently using a WP-3D aircraft also based in Fairbanks with flights from 3 to 23 April 2008 (all but one after 11 April). CO measurements were made by vacuum ultraviolet resonance fluorescence at a frequency of $1 \mathrm{~Hz}$ and accuracy of 5\% (Holloway et al., 2000).

Observed and modeled CO concentrations along the ARCTAS and ARCPAC flight tracks are shown in Fig. 3. Observed concentrations during ARCTAS ranged from 23 to $296 \mathrm{ppbv}$ (excluding observations south of $55^{\circ} \mathrm{N}$ from transit flights). Less than $1 \%$ of the observations had concentrations greater than $250 \mathrm{ppbv}$. Low values signify stratospheric air and are removed for subsequent analysis as described below. Observed concentrations during ARCPAC ranged from 96 to $383 \mathrm{ppbv}$. The highest $\mathrm{CO}$ concentrations were observed over and around Alaska and were due to Asian pollution and Russian fires, as discussed below. High-CO layers were also sampled elsewhere, in particular near the North Pole by the DC-8. The GEOS-Chem simulation with prior emissions (Fig. 3, middle panels) shows qualitative agreement with the observations but quantitative discrepancies are evident. Modeled concentrations are generally too low, although they are sometimes too high in plumes over and around Alaska,

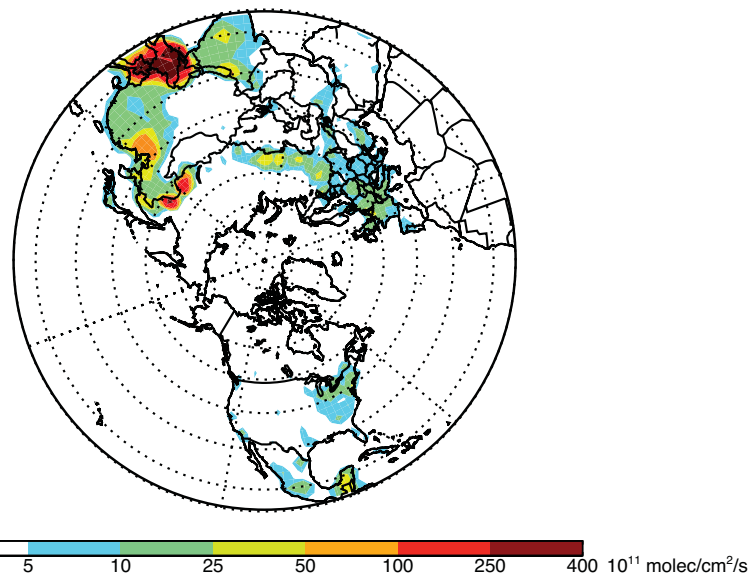

Fig. 1. CO combustion sources for April 2008 (excluding secondary $\mathrm{CO}$ from oxidation of biogenic NMVOCs and methane). Values are shown for the optimized simulation but patterns are similar for the prior simulation.

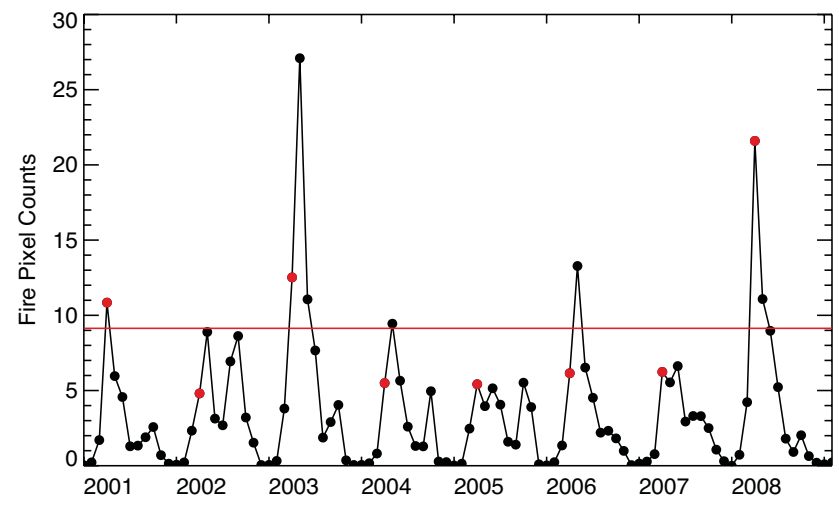

Fig. 2. Monthly mean fire counts (cloud and overpass corrected) for southern Russia and Kazakhstan $\left(33-60^{\circ} \mathrm{N}, 60-152.5^{\circ} \mathrm{E}\right)$ from the MODIS instrument aboard the Terra satellite. Fire counts for April of each year are in red. The red solid line shows the 2001-2008 April mean. Data courtesy of NASA Goddard Earth Sciences Data and Information Services Center.

suggesting different model errors for the different sources affecting the Arctic.

Figure 4 shows the median vertical distribution of the aircraft $\mathrm{CO}$ observations along with the corresponding model values. Stratospheric observations, diagnosed as $\left[\mathrm{O}_{3}\right] /[\mathrm{CO}]$ $>1.25 \mathrm{~mol} \mathrm{~mol}^{-1}$ (Hudman et al., 2007), were removed from the data set. The median observed $\mathrm{CO}$ concentration at the surface was $160 \mathrm{ppbv}$. The data show little or no decrease up to $5 \mathrm{~km}$ and a sharp decrease above. The ARCTAS data show the most variability in the mid-troposphere $(3-6 \mathrm{~km})$. The ARCPAC data show greater variability than the ARCTAS data at all altitudes.

The red lines in Fig. 4 show the median $\mathrm{CO}$ profiles from the GEOS-Chem simulation with prior emissions. Relative 


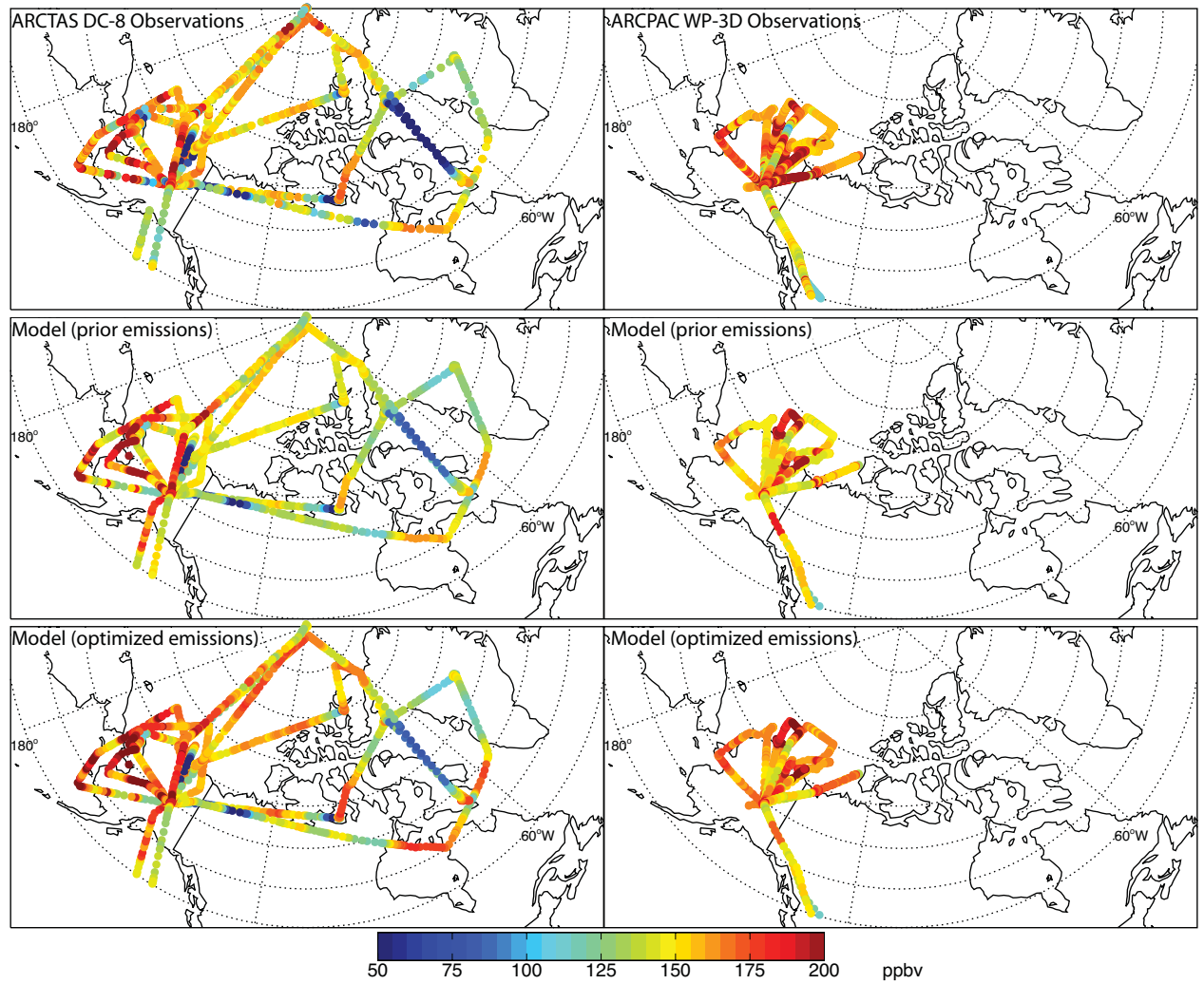

Fig. 3. CO concentrations during ARCTAS (1 to 19 April 2008) and ARCPAC (3 to 23 April 2008). Aircraft observations (top) are compared to model values sampled along the flight tracks and using prior (middle) or optimized (bottom) emissions. The flight tracks extend from 0 to $12 \mathrm{~km}$ (ARCTAS) and $8 \mathrm{~km}$ (ARCPAC); low values correspond to the stratosphere. Observations south of $55^{\circ} \mathrm{N}$ taken during transit flights are excluded. For ARCTAS flights, observed CO concentrations range from 23 to $296 \mathrm{ppbv}$, while modeled concentrations range from 33 to $243 \mathrm{ppbv}$ with prior emissions and 34 to $226 \mathrm{ppbv}$ with optimized emissions. For ARCPAC flights, observed concentrations range from 96 to 383 ppbv, while modeled concentrations range from 112 to $255 \mathrm{ppbv}$ with prior emissions and 115 to 221 ppbv with optimized emissions.

to both aircraft data sets, the model is $10 \mathrm{ppbv}$ too low near the surface. This difference decreases with altitude and disappears in the upper troposphere. The underestimate of $\mathrm{CO}$ at northern extratropical latitudes in spring is a general problem in current CTMs (Shindell et al., 2006b). We correct the discrepancy here by adjusting emissions based on the assumption that emission errors in the model are systematic, model transport errors are random, and model $\mathrm{OH}$ errors are small. We thus estimate the correction to emissions by performing least squares multiple linear regression to the aircraft observations of model results for five tagged tracers of CO sources: (1) North American anthropogenic (fossil fuel and biofuel), (2) European anthropogenic, (3) Asian anthropogenic, (4) Russian biomass burning, and (5) Southeast Asian biomass burning. Emissions from these five sources are assumed to represent the only sources of model error. The regression is performed after first subtracting the modeled contribution from all other sources from the total modeled and observed $\mathrm{CO}$. The resulting fit coefficients represent the source corrections needed to minimize the discrepancy between observations and model. The fit is conducted using all tropospheric data from both ARCTAS (1454 points from 9 flight days) and ARCPAC (1251 points from 9 flight days), including data from transit flights to the Arctic.

Table 2 shows the emission scaling factors from the least squares fit with confidence intervals determined using the bootstrap method. The resulting emission estimates are given in Table 1 and Fig. 1. We find that we need to increase anthropogenic emissions from East Asia and from Europe to correct the underestimate of the background (Fig. 4) and in the eastern part of the ARCTAS domain (Fig. 3). No correction is needed for our North American anthropogenic emissions (Table 2), where our prior emissions are consistent with other observational constraints (Hudman et al., 2008; Kopacz et al., 2010).

Our finding that current anthropogenic emission inventories for Europe and Asia are too low is consistent with the recent inverse model analysis of Kopacz et al. (2010), which was constrained by an ensemble of satellite data (MOPITT, AIRS, and SCIAMACHY) and verified against aircraft and ground-based measurements. They found that the inventories need to be increased in seasons other than 

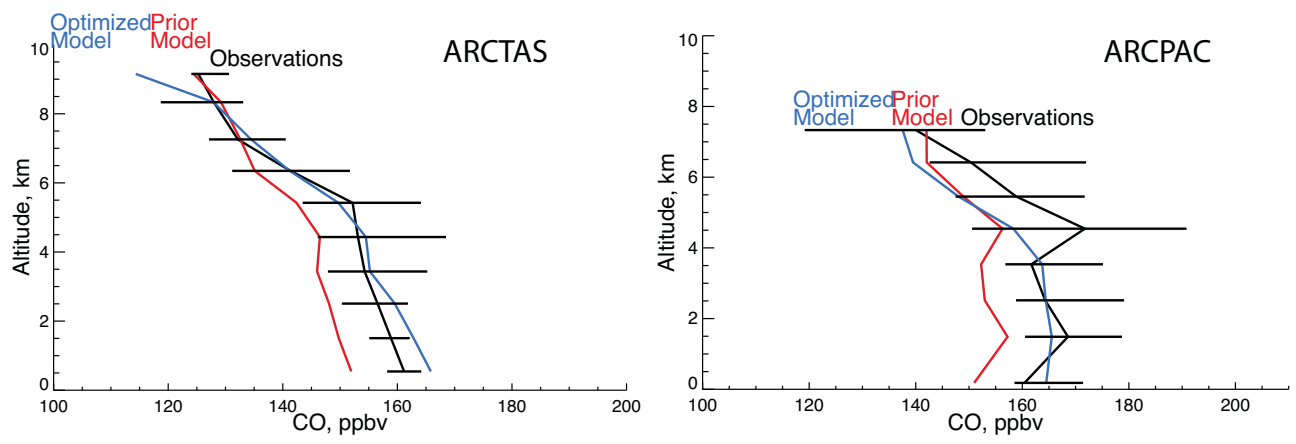

Fig. 4. Median vertical distribution of CO concentrations in ARCTAS (1 to 19 April 2008) and ARCPAC (3 to 23 April 2008), averaged over 1-km altitude bins. Observations are compared to model values with prior and optimized emissions. Black horizontal bars show the interquartile range of the observations. Stratospheric observations identified by $\left[\mathrm{O}_{3}\right] /[\mathrm{CO}]>1.25 \mathrm{~mol} \mathrm{~mol}^{-1}$ have been removed.

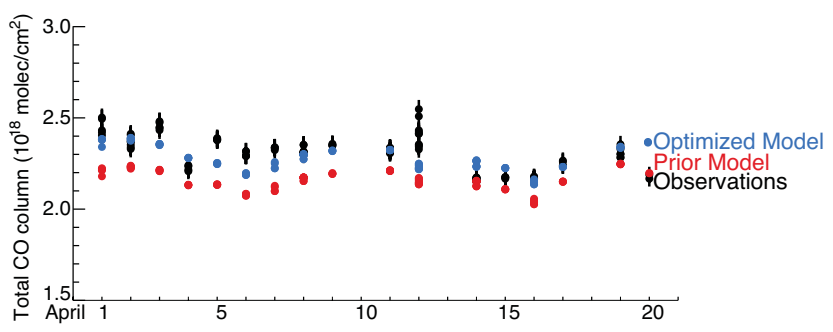

Fig. 5. CO columns at Eureka, Nunavut, Canada $\left(86.4^{\circ} \mathrm{W}, 80.0^{\circ} \mathrm{N}\right)$ from 1 to 20 April 2008. Measurements by a ground-based Fourier Transform Spectrometer are compared to model values with both prior and optimized sources. Black vertical bars show the uncertainties of the measurements.

summer. Their optimized April anthropogenic emissions of 8.0 Tg month ${ }^{-1}$ for Europe and $28 \mathrm{Tg}_{\mathrm{month}}{ }^{-1}$ for Asia are consistent with our estimates of $9.4 \mathrm{Tg} \mathrm{month}^{-1}$ for Europe and $26 \mathrm{Tg}$ month $^{-1}$ for Asia. Kopacz et al. (2010) suggested that the spring underestimate in the inventories may reflect emissions from residential fuel use and vehicle cold starts. These sources are included in the Zhang et al. (2009) inventory used as our prior for Asia but with the assumptions that residential fuel use peaks from November through March and that cold starts have no seasonal variation. It is unlikely that the discrepancy over Asia reflects growth in $\mathrm{CO}$ emissions since 2006 (the base year for the emissions inventory), as recent increased energy use has largely been offset by technology renewals (Zhang et al., 2009).

The ARCTAS and ARCPAC data suggest that we need to decrease biomass burning emissions in the FLAMBE inventory by a factor of 0.5 over southern Russia and by a factor of 0.4 over Southeast Asia. The downward correction results in an optimized estimate of $15 \mathrm{Tg}$ CO from Russian fires and $23 \mathrm{Tg} \mathrm{CO}$ from Southeast Asian fires in April, the latter in agreement with previous estimates of $18-23 \mathrm{Tg}$ month $^{-1}$ (Duncan et al., 2003; Heald et al., 2003b).
Table 2. Correction factors to prior $\mathrm{CO}$ combustion sources in GEOS-Chem ${ }^{\mathrm{a}}$.

\begin{tabular}{ll}
\hline Source & Correction factor \\
\hline North American anthropogenic & $0.96 \pm 0.16$ \\
European anthropogenic & $1.52 \pm 0.18$ \\
Asian anthropogenic & $1.18 \pm 0.11$ \\
Russian biomass burning & $0.53 \pm 0.09$ \\
Southeast Asian biomass burning & $0.45 \pm 0.11$ \\
\hline
\end{tabular}

${ }^{\text {a }}$ Source correction factors to the prior emission inventories of Table 1 , derived using a multiple linear regression between GEOSChem tagged tracers and aircraft observations from ARCTAS (1 to 19 April 2008) and ARCPAC (3 to 23 April 2008) as described in the text. Anthropogenic sources include fossil fuel and biofuel. Errors show the $95 \%$ confidence interval calculated by the bootstrap method.

Modeled CO concentrations from the optimized simulation are shown along the flight tracks in Fig. 3 (lower panels) and the profiles are shown as blue lines in Fig. 4. The source correction eliminates the model error below $4 \mathrm{~km}$ for both campaigns. Above $4 \mathrm{~km}$, the optimization eliminates the error relative to ARCTAS but not ARCPAC. After source correction, the Pearson correlation coefficient between observations and simulation improves from $r=0.50$ to $r=0.60$ for ARCTAS and from $r=0.49$ to $r=0.53$ for ARCPAC. The low correlation coefficients are driven by the high $\mathrm{CO}$ values found in some fine-structure plumes, where large model error is expected due to both plume smearing and displacement (Rastigejev et al., 2010). We tried removing the plumes before performing the least squares fit but this did not significantly alter the resultant source correction factors.

To further test the optimization of sources, we conducted independent comparisons with observations using CO column data from a surface site at Eureka, Nunavut $\left(80^{\circ} \mathrm{N}, 86^{\circ} \mathrm{W}\right)$ and from the AIRS satellite instrument. The measurements at Eureka were made with a Bruker Fourier Transform Spectrometer (FTS) (Batchelor et al., 

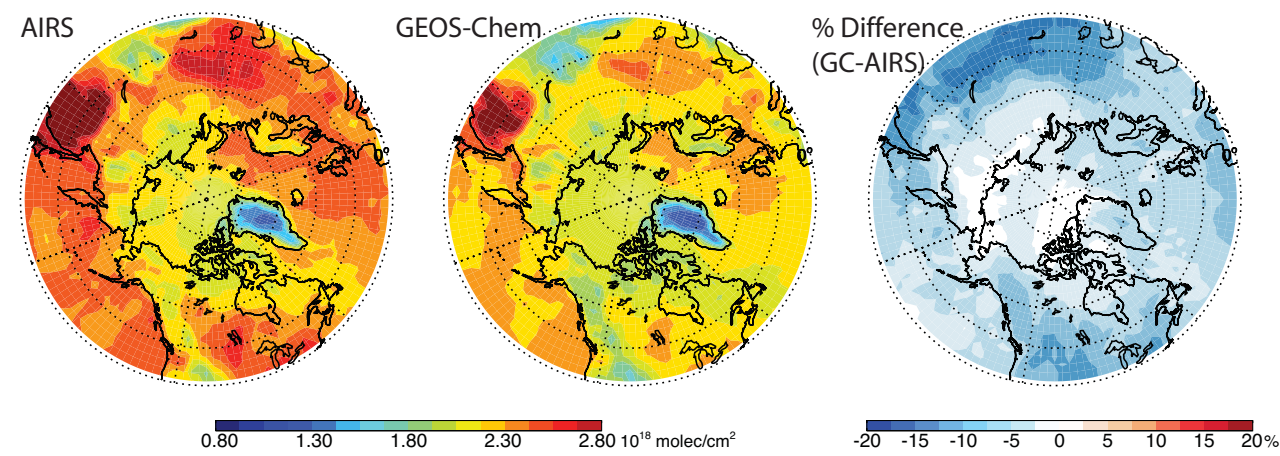

Fig. 6. Mean CO columns during April 2008 observed by the AIRS satellite instrument (version 5) and simulated by GEOS-Chem with optimized sources (and AIRS averaging kernels applied). The right panel shows the percent difference between the two. GEOS-Chem was sampled along the AIRS orbit tracks at the time of successful retrievals (see text).
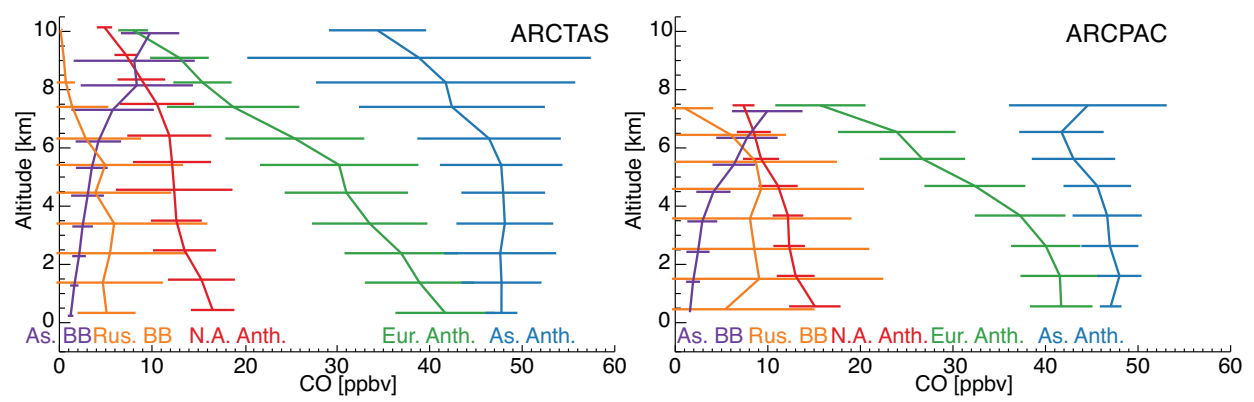

Fig. 7. Median vertical distribution along the ARCTAS and ARCPAC flight tracks of GEOS-Chem CO concentrations tagged by source region and type: Asian anthropogenic (As. Anth., blue), European anthropogenic (Eur. Anth., green), North American anthropogenic (N.A. Anth., red), Russian biomass burning (Rus. BB, orange) and Southeast Asian biomass burning (As. BB, purple). Horizontal bars are standard deviations.

2009). Intercomparison with the DC-8 during a spiral over the site on 8 April 2008 showed agreement within $0.01 \times 10^{18}$ molecules $\mathrm{cm}^{-2}(0.5 \%)$. Figure 5 shows that the source correction reduces the mean model bias relative to observations from $-6 \%$ with prior sources to $-1 \%$ with optimized sources.

Figure 6 shows the mean April 2008 AIRS CO columns compared to the GEOS-Chem model values from the optimized simulation. Both AIRS and GEOS-Chem show the highest pollution levels in the European sector of the Arctic, followed by the Asian sector. The North American Arctic is least polluted. Transport of European pollution takes place directly northward over Scandinavia, while transport from Asia is northeastward, entering the Arctic over Siberia and Alaska. Averaged over the Arctic, GEOS-Chem is 3\% lower than AIRS. Comparison with the prior simulation (not shown) revealed positive errors over the southern Russian fire source and outflow regions due to the significant overestimate of fire emissions. Meanwhile, the optimized GEOSChem simulation shows the largest underestimate over the region of the Russian fires, which may indicate that the factor of two downward correction to the FLAMBE inventory is too large.

\section{Sources of Arctic pollution in April 2008}

We use the GEOS-Chem tagged tracers to decompose the optimized simulated $\mathrm{CO}$ vertical profiles from ARCTAS and ARCPAC (Fig. 4, blue lines) into the contributions from individual sources. Figure 7 shows the median profiles along the flight tracks of the five dominant sources, which on average account for $67 \%$ of total $\mathrm{CO}$ during the campaigns. For both campaigns, mean concentrations are dominated by Asian anthropogenic emissions along with a substantial contribution from European anthropogenic emissions, especially at low altitude. These mean contributions largely reflect the wintertime accumulation of $\mathrm{CO}$ over the scale of the northern extratropical hemisphere. Emissions from Russian fires, which did not begin until April (Fig. 2), have much less impact on the mean pollution influence.

Conversely, Russian biomass burning makes a large contribution to $\mathrm{CO}$ variability (horizontal bars in Fig. 7). During ARCPAC, the variability at all altitudes is dominated by the Russian biomass burning source, consistent with the large biomass burning plume influence observed during the campaign (Warneke et al., 2008). The Russian biomass burning contribution is smaller during ARCTAS and 


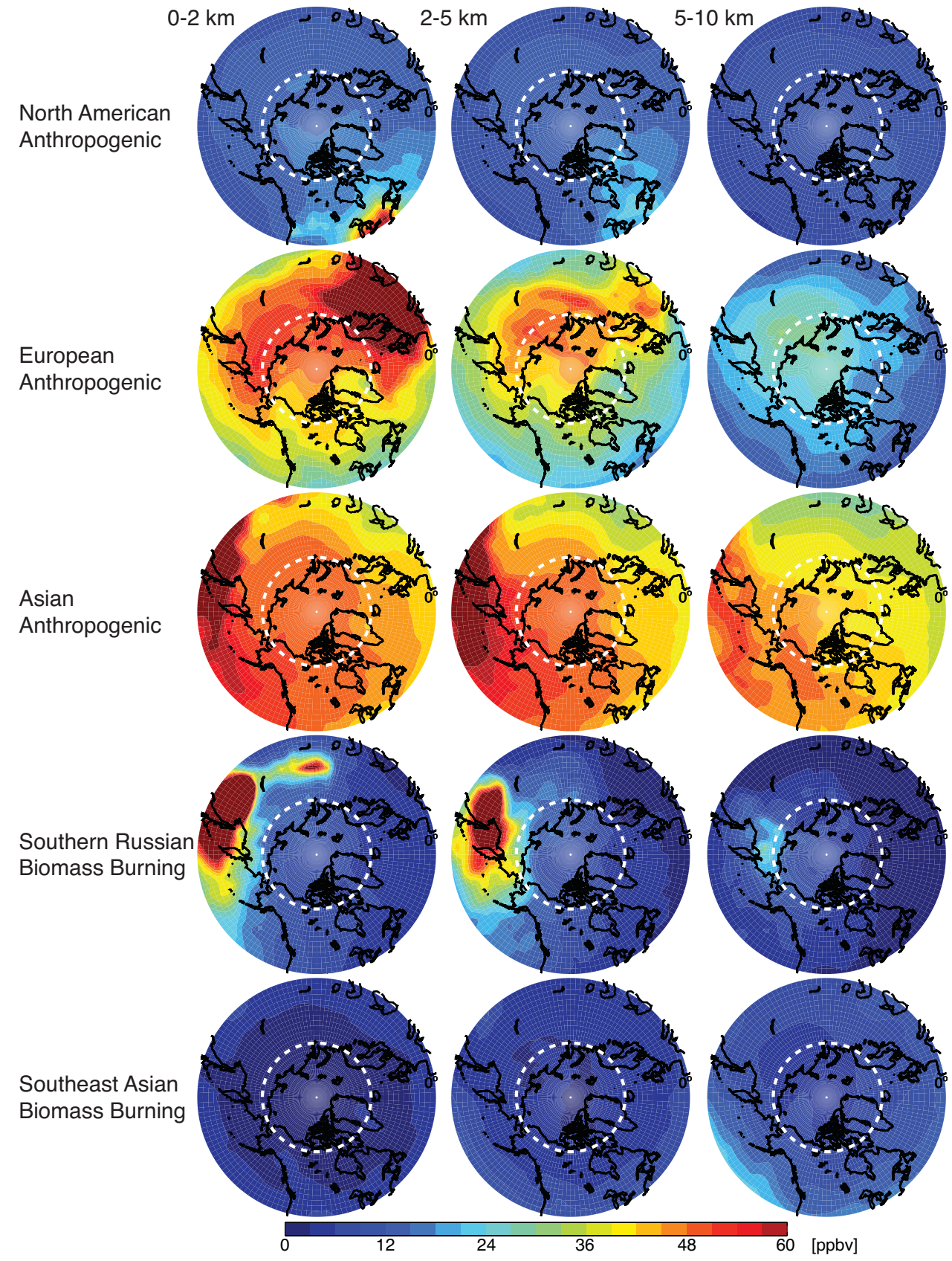

Fig. 8. Contributions of different mid-latitude source regions to CO pollution in the Arctic in April 2008, as indicated by the GEOS-Chem simulation. Results are shown as mean CO mixing ratios in altitude bands of $0-2,2-5$, and $5-10 \mathrm{~km}$. The Arctic Circle is indicated by a dashed white line.

is comparable to the contributions from the continental anthropogenic sources, reflecting differences in sampling strategy between the two campaigns. The Asian anthropogenic and Southeast Asian biomass burning sources dominate variability in the upper troposphere for the ARCTAS flights. This reflects the dominant pathway of Asian outflow in spring involving uplift in WCBs off the Pacific coast, as was previously observed in the TRACE-P aircraft campaign (Liu et al.,
2003). Stohl (2006) identified this as the only major transport pathway from Asia to the Arctic, with subsequent influence at the Arctic surface involving subsidence on a time scale of a month. The lifetime of CO is sufficiently long for this subsidence to operate, leading to a general Asian pollution influence in the Arctic background. 
Figure 8 shows the April 2008 mean contributions of each tracer in different altitude bands over the scale of the Arctic. Asian anthropogenic emission is the dominant contributor throughout the Arctic above $2 \mathrm{~km}$, reflecting the highaltitude WCB transport pathway. There is some lifting of European pollution affecting the middle troposphere in the European and Siberian sectors of the Arctic. In the boundary layer, Asian and European anthropogenic influences are of comparable magnitude but have distinct geographical signatures. European influence dominates in the European sector of the Arctic, reflecting near-surface northward transport over Scandinavia, and also over eastern Siberia, reflecting westerly transport. We see from Fig. 8 that this trans-Siberian transport is the dominant pathway by which European pollution affects Alaska. Our finding of European influence lifted to the middle troposphere and transported across Siberia in April differs from the prevailing winter situation (Klonecki et al., 2003; Stohl, 2006) when European pollution is strongly confined to the boundary layer and the circulation around the Siberian high carries it to the Arctic rather than eastward across Siberia.

Relative to other anthropogenic sources, pollution from North America makes little contribution to Arctic background concentrations. North American influence is limited to the lowest $5 \mathrm{~km}$ and to the Canadian Archipelago, Davis Strait, and Greenland. Like Asian sources, North American emissions reach the Arctic via uplift and transport associated with WCBs (Stohl, 2006); however, CO emissions in North America are much weaker than in Asia (Table 1).

Shindell et al. (2008) previously found in a multi-model $\mathrm{CO}$ intercomparison that the Arctic in spring was most sensitive to European sources, followed by North American then Asian sources. The difference with our results reflects the magnitude of emissions. The multi-model mean total emissions (anthropogenic and biomass burning) in Shindell et al. (2008) were 156, 90, and $129 \mathrm{Tg} \mathrm{a}^{-1}$ for East Asia, Europe, and North America, respectively; whereas our corresponding totals are 234,135 , and $77 \mathrm{Tg} \mathrm{a}^{-1}$ for anthropogenic sources alone. Our higher Asian emissions and lower North American emissions are consistent with recent inverse analyses (Heald et al., 2004; Streets et al., 2006; Hudman et al., 2008; Tanimoto et al., 2008; Fortems-Cheiney et al., 2009; Kopacz et al., 2009, 2010).

Although Southeast Asian fires were a large northern hemispheric source of CO during April 2008 (Fig. 1 and Table 1), their influence on the Arctic is minimal because of the low latitude of emissions and the dominance in spring of venting by deep convective events (Liu et al., 2003). The small fraction of these emissions that reaches the Arctic does so in the upper troposphere (Figs. 7 and 8), reflecting isentropic transport (Klonecki et al., 2003) along with transport by WCBs (Bey et al., 2001; Liu et al., 2003; Liang et al., 2004). Even in the upper troposphere, the Southeast Asian fire influence is smaller than the Asian anthropogenic influence.

\section{Variability of Arctic pollution observed by AIRS}

AIRS provides a unique perspective on variability of transport to the Arctic. In this section we first test the ability of AIRS to observe long-range pollution transport to the Arctic by investigating two pollution events of different origins observed by the aircraft during ARCTAS. We then assess the representativeness of the April 2008 observations using the AIRS multi-year record (2003-2008) and more generally interpret the interannual variability observed by AIRS.

AIRS version 5 total column retrievals for 2003-2007 have been validated against FTIR data at three high latitude sites and show excellent agreement (Yurganov et al., 2009). At $\mathrm{Ny}$ Alesund $\left(80^{\circ} \mathrm{N}\right)$, the mean annual bias is near zero. Mean bias is also near zero at Kiruna $\left(68^{\circ} \mathrm{N}\right)$ and Harestua $\left(60^{\circ} \mathrm{N}\right)$ for DOF for signal greater than 0.7 , but negative biases are observed at lower DOF. Overall, northern hemispheric AIRS total column observations in April show an $8 \%$ negative bias relative to FTIR data. Validation of AIRS $\mathrm{CO}$ retrievals in the northern hemisphere with aircraft in situ profiles indicates AIRS is biased approximately 10\% high from $300-900 \mathrm{mb}$ with little quantitative sensitivity to the boundary layer, like all thermal IR sounders (McMillan et al., 2009). In the Arctic, this lack of sensitivity may be compounded by the cold surface. We therefore expect AIRS to be capable of identifying transport to the Arctic in the midtroposphere but not at low altitude, and test this below with two case studies of pollution plumes observed by ARCTAS.

Figure 9 shows CO concentrations on 16 April 2008 observed by the DC- 8 aircraft and total column CO observed by AIRS, together with the corresponding GEOS-Chem values. $\mathrm{CO}$ concentrations of up to $250 \mathrm{ppbv}$, among the highest during the ARCTAS campaign, were observed at altitudes of $3.5-5 \mathrm{~km}$ over western Alaska and the Norton Sound during this flight. The enhancement was well captured by GEOSChem, which shows the source to be a mix of Asian pollution and Eurasian fires. Further evidence for a biomass burning source comes from elevated observations of hydrogen cyanide $(\mathrm{HCN})$ and acetonitrile $\left(\mathrm{CH}_{3} \mathrm{CN}\right)$. More than half of the back trajectories shown in Fig. 10 passed directly over the agricultural fires in southeastern Russia and Kazakhstan at low altitude before being lifted, likely by WCBs, to the mid-troposphere. Turning to the satellite observations, we see qualitative agreement between measured and simulated total column CO throughout the Arctic, although AIRS is consistently higher than GEOS-Chem as previously discussed. Both AIRS and GEOS-Chem show an extensive plume stretching from Eastern Russia across the Pacific to Alaska. Forward trajectories from the sampled plume indicate that the plume did not travel poleward after being sampled; however, it eventually entered the Arctic over the Canadian Archipelago and the Davis Strait eight to ten days later. This example illustrates AIRS's ability to observe WCB lofting and outflow from Eurasia to the Arctic. 

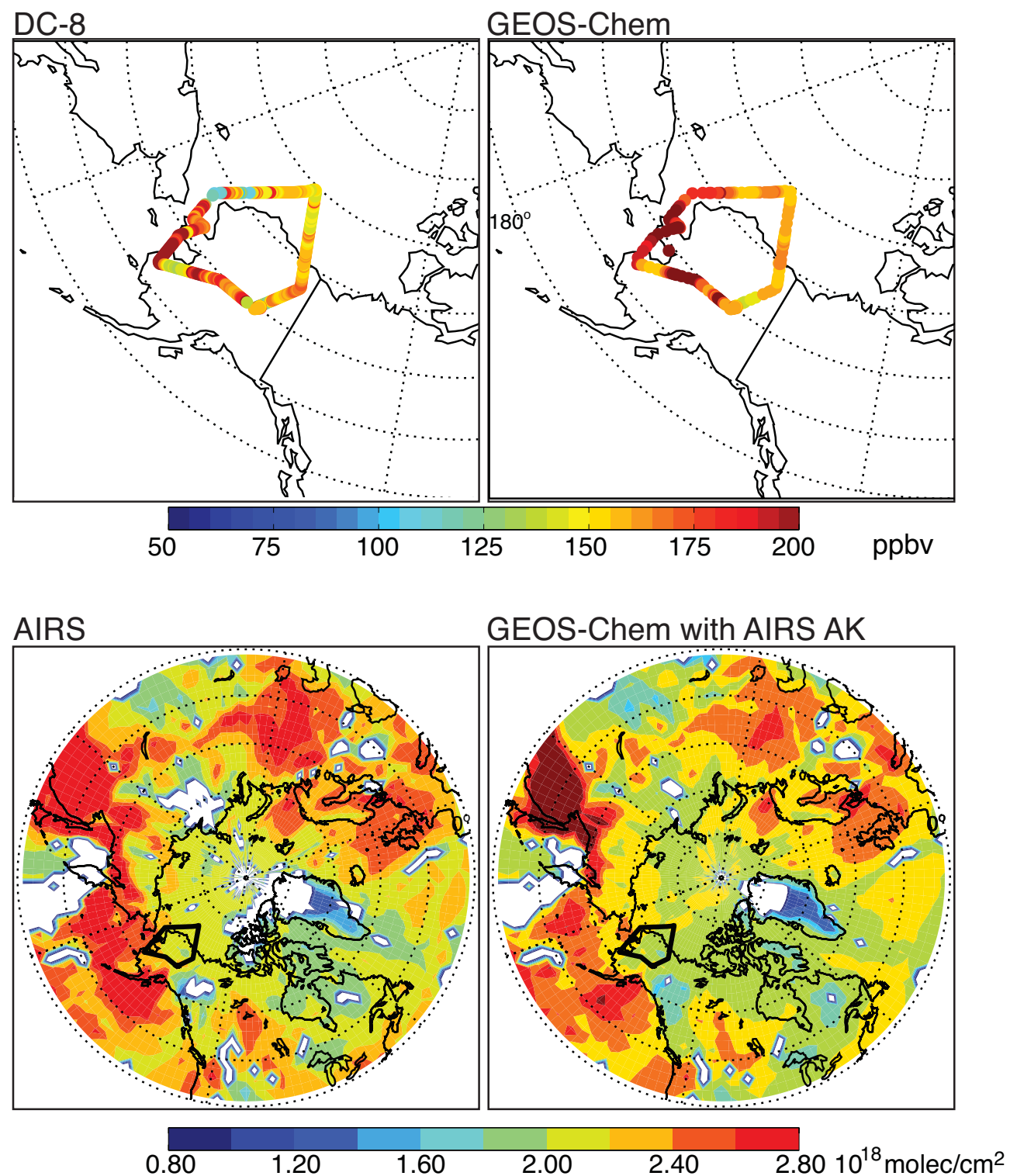

Fig. 9. Russian biomass burning event over Alaska sampled by the DC- 8 aircraft on 16 April 2008. The top panels show aircraft observations of CO concentrations compared to the GEOS-Chem model. The bottom panels show the AIRS CO column concentrations observed on that day compared to the GEOS-Chem model with AIRS averaging kernels applied.

Figure 11 shows a different case on 9 April 2008, when a $\mathrm{CO}$ enhancement was observed by the aircraft at the North Pole at altitudes below $2 \mathrm{~km}$. Concentrations in the plume were 165-170 ppbv. Backward trajectories (Fig. 12) indicate that the plume traveled slowly from northeastern Europe across Siberia, remaining at low altitude. Although trajectories pass over the Russian burning region, this was before the most intense fires began, and observed concentrations of $\mathrm{HCN}$ and $\mathrm{CH}_{3} \mathrm{CN}$ were negligible. GEOS-Chem captures the plume and indicates that the primary source was European pollution mixed with some Asian pollution. Forward trajectories show that much of the polluted airmass remained

www.atmos-chem-phys.net/10/977/2010/ at low altitude over the pole for at least the next ten days. We do not expect AIRS to be sensitive to such low-altitude transport, and indeed we see from Fig. 11 that neither AIRS nor the GEOS-Chem simulation weighted by AIRS averaging kernels could detect the plume.

The limited ability of AIRS to observe low-altitude CO enhancements prevents us from using AIRS to systematically identify near-surface transport events to the Arctic. As we have shown with the GEOS-Chem simulation, this mainly impacts our interpretation of pollution from European sources, which is primarily (though not exclusively) transported at low altitude. AIRS is most useful for identifying 


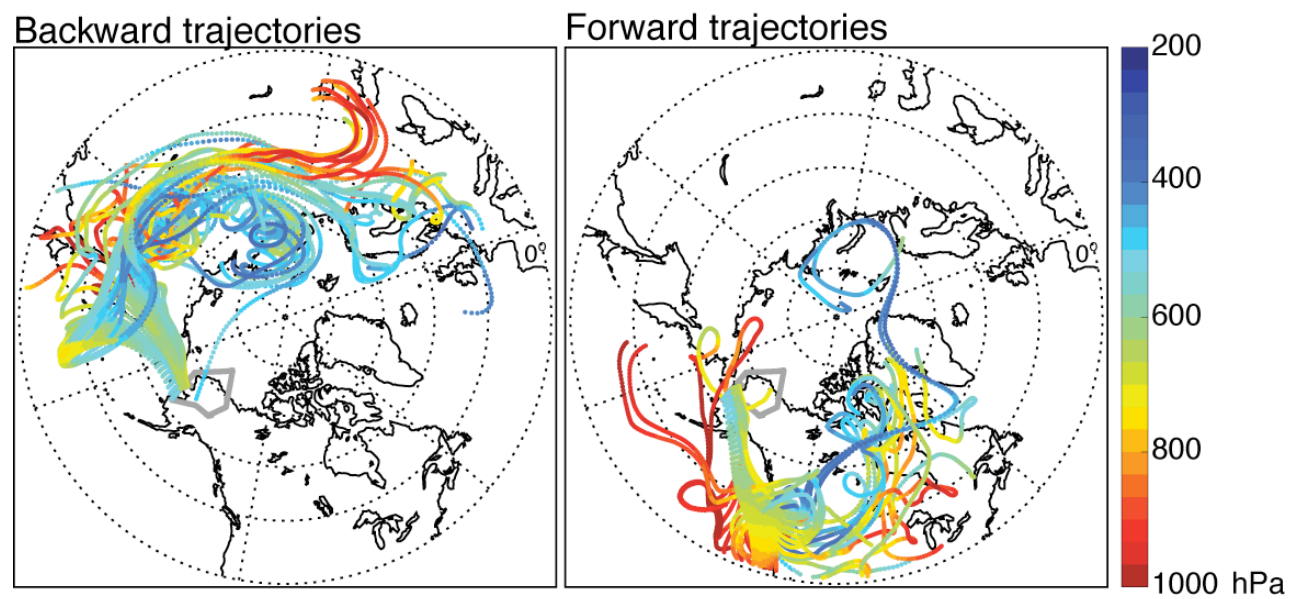

Fig. 10. Ten-day backward and forward trajectories from the FLEXPART model using WRF meteorological fields and starting from the 16 April 2008 plume shown in Fig. 9. The color scale indicates altitude.

mid-tropospheric transport, which as we have seen privileges Asian influence.

The 2003-2008 April mean CO columns from AIRS are shown in Fig. 13, along with the anomalies for each year. The major features described for 2008 (Fig. 6 and Sect. 3) are also seen in the multi-year mean, with the European sector of the Arctic being the most polluted and the North American sector the cleanest. The anomaly maps show little variability north of the Arctic Circle. Mean April CO column ranges from $2.06 \times 10^{18}$ molecules $\mathrm{cm}^{-2}$ to $2.11 \times 10^{18}$ molecules $\mathrm{cm}^{-2}$, despite larger year-to-year differences at mid-latitudes, and is most strongly correlated with mean Arctic sea level pressure (SLP) in the GEOS5 data $(r=-0.81)$. We attribute this anti-correlation to the higher degree of Arctic isolation associated with high pressure conditions, preventing poleward transport of $\mathrm{CO}$ from mid-latitudes.

Pollution transport to the Arctic is thought to be enhanced under the positive phase of the North Atlantic Oscillation (NAO) (Eckhardt et al., 2003; Duncan and Bey, 2004) due to stronger surface westerlies and anomalous southerly flow (Hurrell et al., 2003). Previous studies found strong positive correlations, most pronounced at the surface, between NAO strength and Arctic pollution accumulation in winter and spring (Eckhardt et al., 2003; Duncan and Bey, 2004). However, we find no significant correlation of AIRS CO over the Arctic in April 2003-2008 with the February-April mean NAO index (taken from the NOAA Climate Prediction Center, available at http://www.cpc.noaa.gov). This could reflect limitations due to (1) our focus on spring, when the NAO index is typically weak (Hurrell et al., 2003), (2) the lack of sensitivity of AIRS to surface concentrations where the correlation is strongest, and (3) the limited range of NAO index variability (less than \pm 1 ) over the 2003-2008 period of the AIRS record.
AIRS observations for April 2008 show that despite the anomalously large Russian fire source, pollution influence over Alaska was much weaker than normal (Fig. 13). This can be explained by a strong SLP anomaly, as shown in Fig. 14. Positive pressure anomalies of more than $10 \mathrm{hPa}$ were seen over the North Pacific with weaker negative anomalies further north, indicating that the climatological Aleutian low pressure system was less intense and shifted northward. Considering that the Aleutian low and associated storm tracks are a major driver for transport of Asian pollution to the Arctic (Fuelberg et al., 2010), this transport may have been weaker than normal in April 2008.

We further examined the interannual variability of the AIRS April CO column over Alaska and find that it is highly correlated $(r=0.80)$ with the February-April mean Ocean Niño Index (ONI, a measure of the El Niño-Southern Oscillation, again taken from the NOAA Climate Prediction Center), as shown in Fig. 15. The correlation is significant at the $p=0.10$ level. Atmospheric teleconnections from ENSO have long been known to affect the strength and position of the Aleutian low pressure system (Bjerknes, 1966; Niebauer, 1988). During El Niño conditions, the Aleutian low intensifies and shifts to the southeast of its climatological mean position $\left(52^{\circ} \mathrm{N}, 175^{\circ} \mathrm{E}\right.$; Rodionov et al., 2005), while during La Niña conditions it weakens and shifts to the west. Niebauer (1988) found that this change alters the low-level flow over the central Pacific, bringing Asian outflow north toward Alaska during El Niño years (see his Fig. 7) and decreasing the northward flow of Asian air during La Niña years. We suspect that this mechanism extends to higher altitudes and explains the correlation between the ONI and the AIRS CO column over Alaska. While there have been no strong El Niño years since the beginning of the AIRS record, a moderate La Niña with monthly ONI values up to -1.4 occurred from fall 2007 through spring 2008, resulting in a 

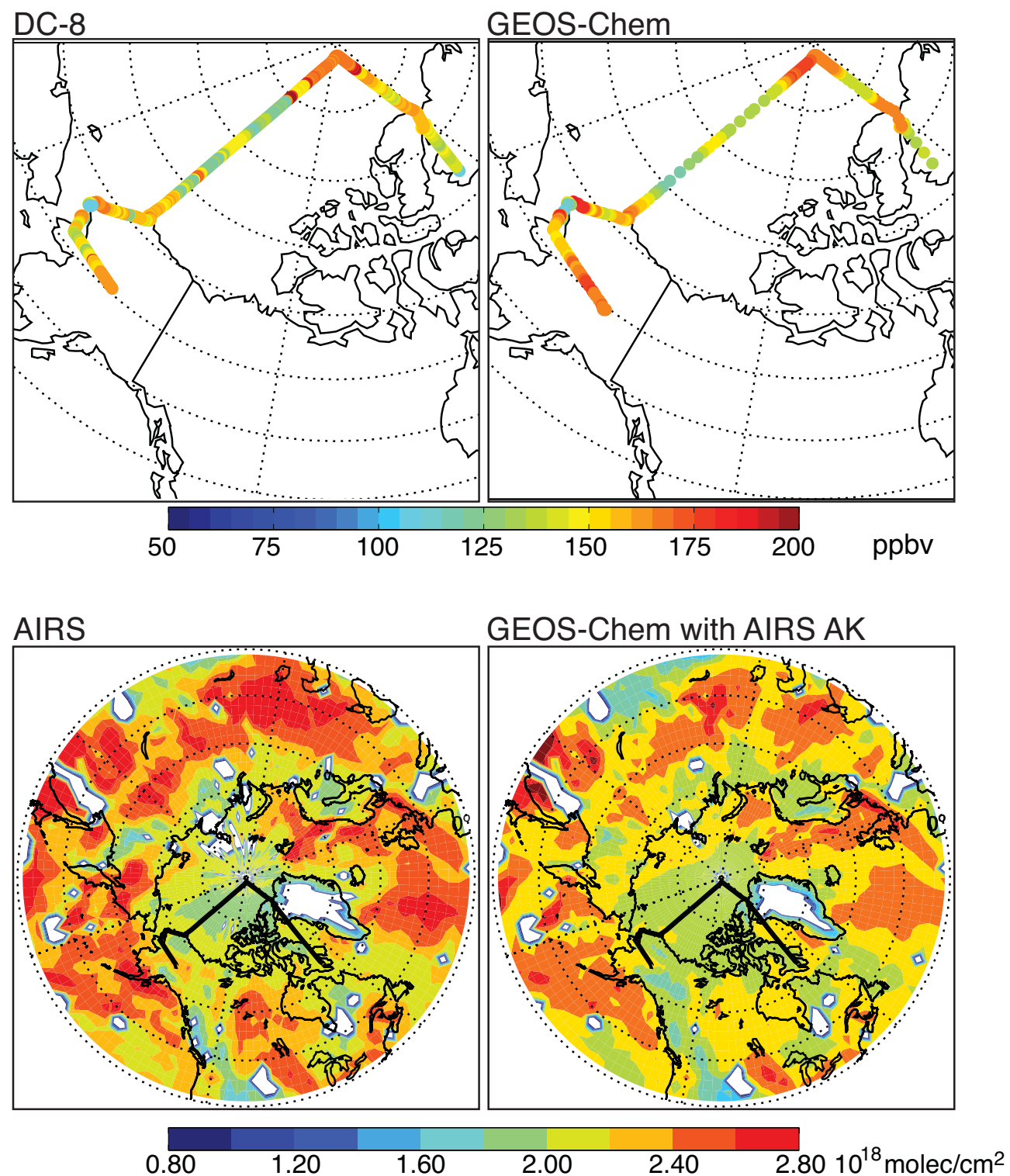

Fig. 11. Same as Fig. 9, but for a European pollution event at the North Pole on 9 April 2008.

less intense Aleutian low and an associated decrease in Asian pollution influence during April 2008. The La Niña persisted through April $(\mathrm{ONI}=-0.8)$ and began to dissipate in May.

The specific meteorological conditions that characterized April 2008 have important implications for the interpretation of the ARCTAS and ARCPAC aircraft data. As discussed in Sect. 4, we find from these data that $\mathrm{CO}$ pollution throughout the Arctic is dominated by the Asian anthropogenic source, despite the anomalously weak poleward transport from this source in April 2008. El Niño conditions would be expected to lead to larger Asian influence and consequently more $\mathrm{CO}$ pollution in the Arctic. Such an effect may be further amplified by increased biomass burning, which has been shown to play a dominant role in increasing $\mathrm{CO}$ concentrations over
Alaska during El Niño events (Szopa et al., 2007). In 2003, the only El Niño year in our record, CO columns were indeed anomalously high over Alaska, the Chukchi Sea, and much of the North American Arctic (Fig. 13).

We further investigated the relationship between ENSO and $\mathrm{CO}$ concentrations in the Alaskan Arctic using GEOSChem. GEOS-5 meteorological fields are available only for 2005-2008, so we performed a sensitivity simulation using meteorology from 2005 (the highest ONI for those four years, see Fig. 15) while maintaining emissions at $2008 \mathrm{lev}$ els. Figure 16 compares simulated concentrations of the Asian fossil fuel tagged tracer in April using 2005 and 2008 meteorology. April 2005 shows stronger northward transport of Asian pollution over the North Pacific and Alaska than 


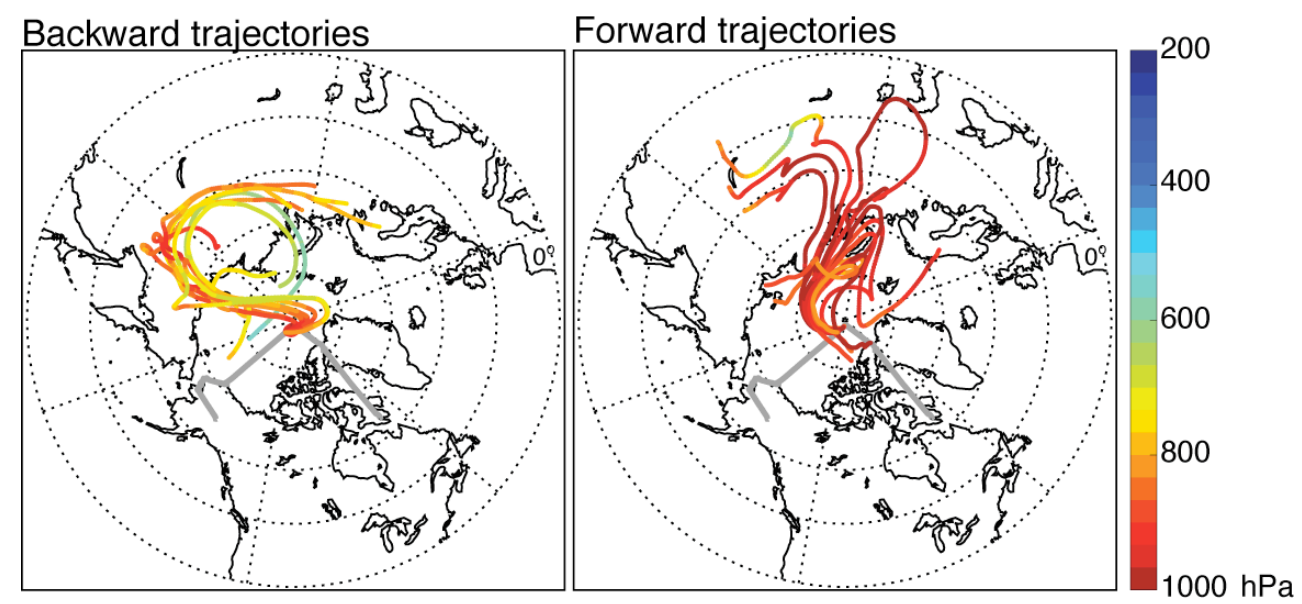

Fig. 12. Same as Fig. 10, but for the European pollution event on 9 April 2008 shown in Fig. 11.
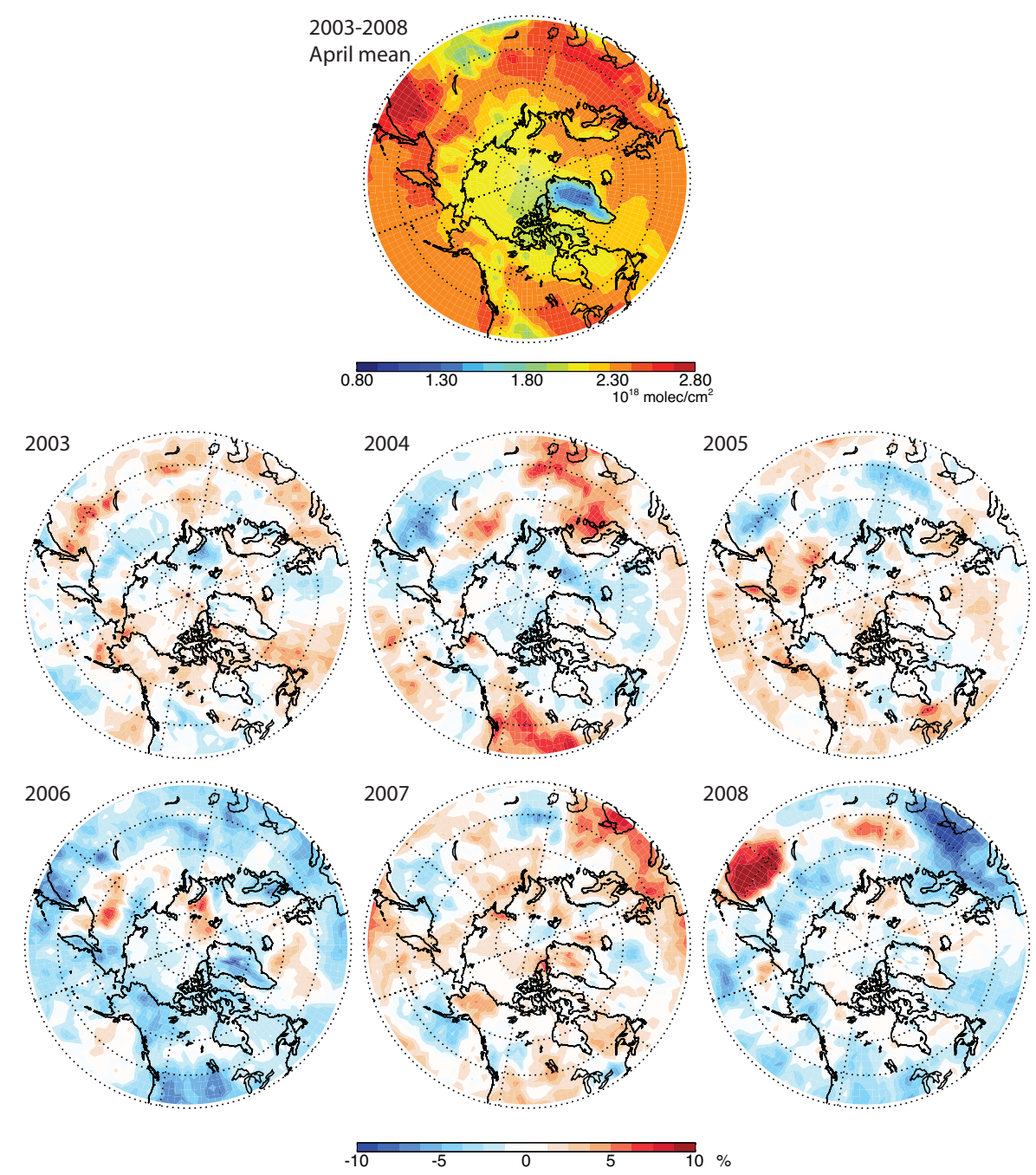

Fig. 13. 2003-2008 mean April CO columns from AIRS (top) and CO column anomalies for each April in the AIRS record. 

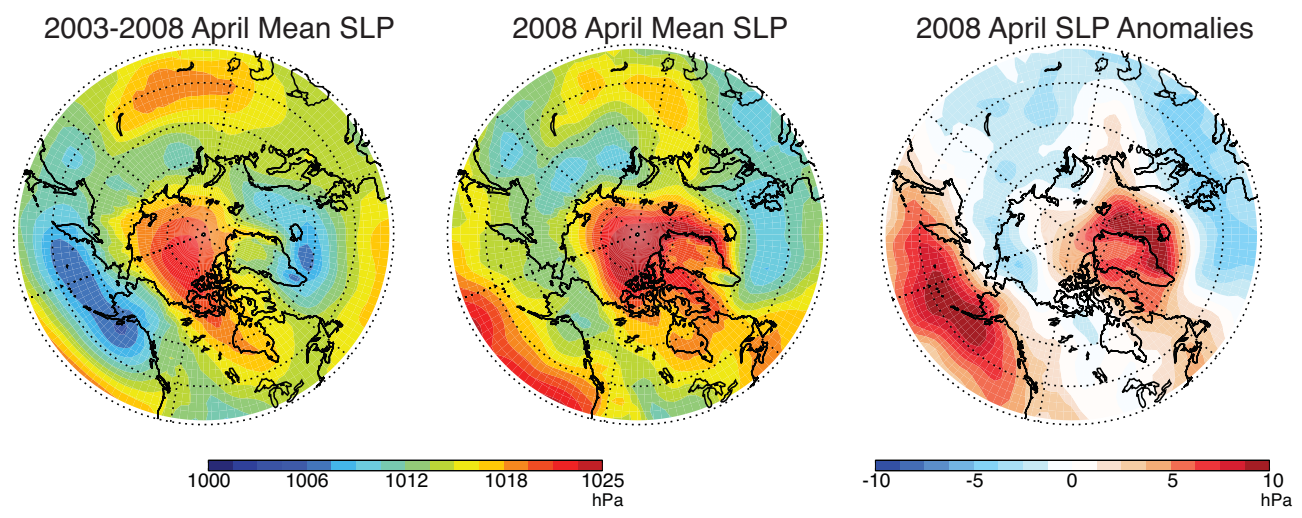

Fig. 14. Mean sea level pressures from GEOS-5 for April 2003-2008 (left) and 2008 only (middle). The 2008 anomaly is shown at right.

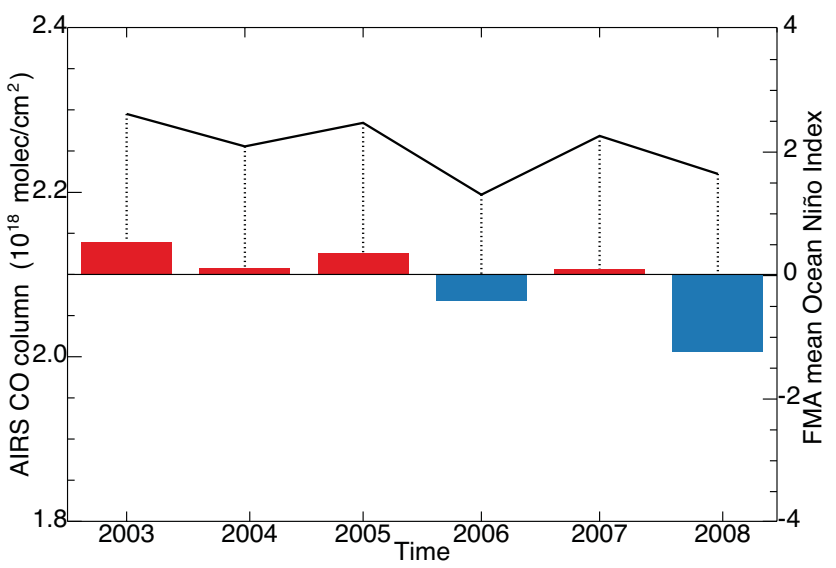

Fig. 15. Year-to-year variability of the mean April AIRS-observed CO column over Alaska $\left(168-140^{\circ} \mathrm{W}, 54-72^{\circ} \mathrm{N}\right)$ and mean Ocean Niño Index (ONI) averaged over February-April for each year. Positive values of the ONI (red) indicate El Niño conditions while negative values (blue) indicate La Niña conditions. The Pearson correlation coefficient of $r=0.80$ is significant at the $p=0.10$ level. The ONI data were obtained from the NOAA Climate Prediction Center, available at http://www.cpc.noaa.gov.

April 2008. Whether this enhancement is indeed linked to the more positive phase of the ONI in 2005 is unclear, and additional data and simulations during a strong El Niño year would be needed to verify this link.

\section{Conclusions}

We used CO observations from the NASA ARCTAS and NOAA ARCPAC aircraft campaigns as top-down constraints in a global 3-D chemical transport model (GEOS-Chem) to quantify the sources of pollution to the Arctic in spring 2008. Through comparisons with aircraft and GEOS-Chem, we demonstrated that AIRS satellite measurements of CO captured the mean spatial structure of Arctic pollution in April
2008 as well as events in the free troposphere but did not detect events in the boundary layer because of low sensitivity in the thermal IR. We subsequently used the 2003-2008 record of AIRS CO observations in the Arctic in April to investigate the interannual variability of pollution transport from northern mid-latitudes.

Least squares regression of the GEOS-Chem CO simulation to the ARCTAS and ARCPAC aircraft observations suggests that anthropogenic $\mathrm{CO}$ emissions in Europe in April 2008 are underestimated by $50 \%$ in the EMEP inventory and anthropogenic emissions in Asia are underestimated by $20 \%$ in the Streets et al. (2006) inventory updated for 2008. The discrepancy likely represents an underestimate of seasonal $\mathrm{CO}$ emissions rather than a problem in global annual emissions. This result is consistent with the recent inverse analysis of Kopacz et al. (2010) and may reflect a winter-spring underestimate of emissions from residential fuel use and vehicle cold starts. April 2008 saw anomalous fire activity in southern Russia in addition to seasonal biomass burning in Southeast Asia. We find that the FLAMBE inventory with hourly resolution based on MODIS and GOES fire data overestimates these emissions by a factor of two. Optimized April 2008 emissions obtained by fitting GEOS-Chem to the ARCTAS aircraft data are $26 \mathrm{Tg}$ month $^{-1}$ for Asian anthropogenic, $9.4 \mathrm{Tg}$ month $^{-1}$ for European anthropogenic, $4.1 \mathrm{Tg}^{\mathrm{month}}{ }^{-1}$ for North American anthropogenic, $15 \mathrm{Tg}_{\mathrm{month}}{ }^{-1}$ for Russian biomass burning, and $23 \mathrm{Tg}$ month $^{-1}$ for Southeast Asian biomass burning. The resulting simulation shows no significant bias (mean of $-1 \%$ ) relative to ground-based column data at Eureka $\left(80^{\circ} \mathrm{N}, 86^{\circ} \mathrm{W}\right)$. It also shows a $-3 \%$ underestimate relative to AIRS in the Arctic, although this may reflect in part a high bias in the AIRS data (McMillan et al., 2009).

We find in GEOS-Chem that CO concentrations over the Arctic in spring are dominated at all altitudes by Asian anthropogenic sources. The exception is at the surface where European anthropogenic sources are of comparable importance. This anthropogenic dominance, despite the large 


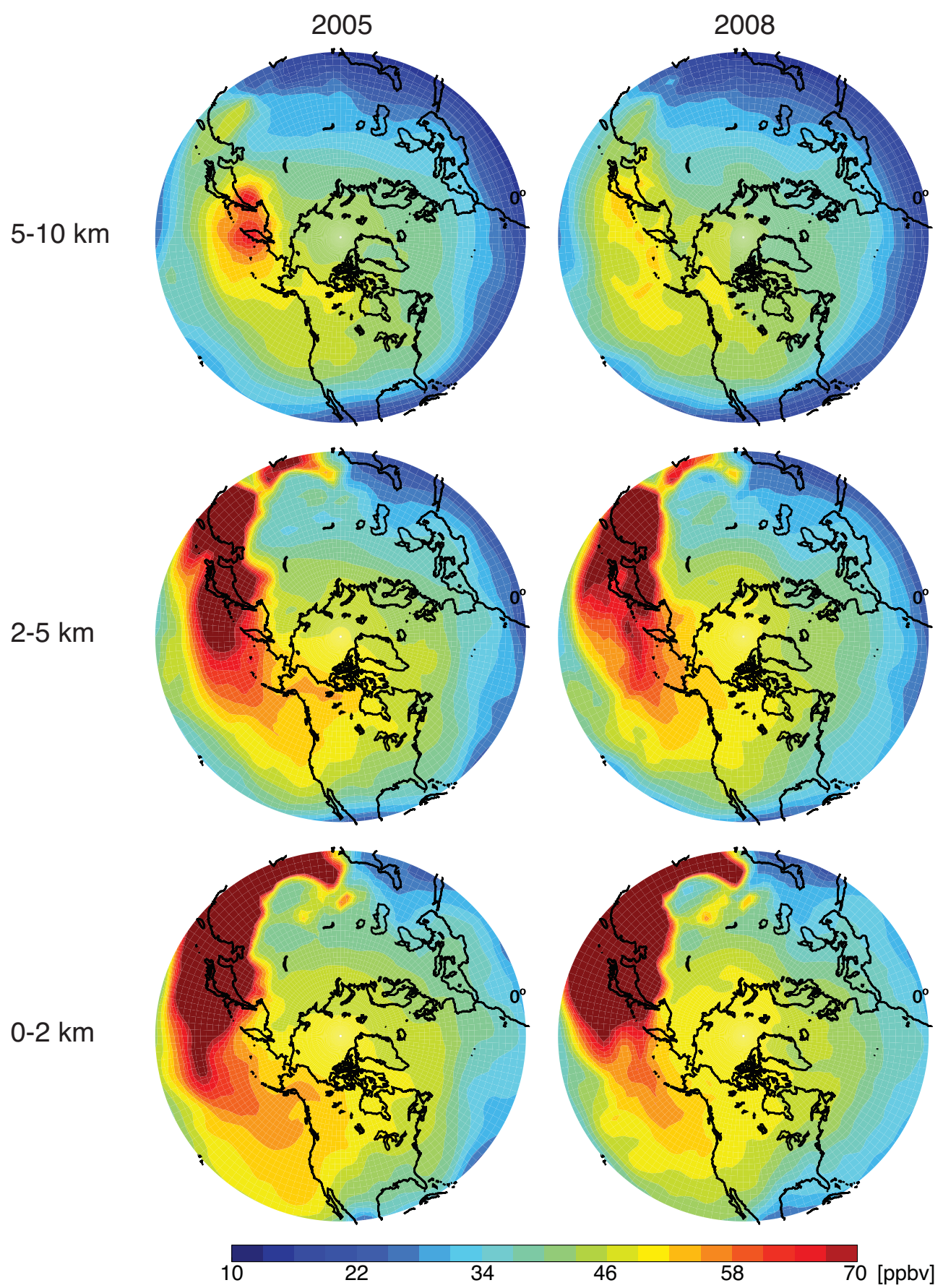

Fig. 16. Concentrations of the Asian fossil fuel CO tagged tracer in the GEOS-Chem simulation for April 2005 versus April 2008 meteorology with identical April 2008 emissions for both years. Results are shown as April mean CO mixing ratios at 0-2, 2-5, and 5-10 km.

biomass burning emissions in April 2008, reflects the wintertime accumulation of anthropogenic $\mathrm{CO}$ on the scale of the northern extratropics. European pollution influence in April extends to the free troposphere and also across Siberia following westerly flow. This contrasts with the prevailing pattern in winter when stratification confines European pollution to the surface and the Siberian high pressure system sup- presses westerly transport. Russian biomass burning makes little contribution to mean $\mathrm{CO}$ but contributes substantially to $\mathrm{CO}$ variability. Asian and biomass burning synoptic transport events take place mainly in the free troposphere through warm conveyor belts (WCBs) and are followed by slow subsidence. Analysis of specific pollution events sampled by the aircraft shows that AIRS can successfully observe the 
long-range transport of pollution to the Arctic in the middle troposphere but not at the surface.

AIRS CO observations in April, both for 2008 and for the multiyear record (2003-2008), show the highest levels of pollution in the European Arctic sector, followed by the Asian sector and with the North American sector being cleanest. This is consistent with GEOS-Chem, where synoptic lifting of European pollution contributes to the European sector. The North American sector is relatively clean, despite WCB injections off the east coast of North America, because $\mathrm{CO}$ emissions there are relatively small. Mean April AIRS CO columns for 2003-2008 show little interannual variability when averaged over the Arctic polar cap. What little variability exists is most strongly correlated with Arctic sea level pressure $(r=-0.81)$ and can be explained by decreased pollution inflow from mid-latitudes under high-pressure conditions. We find little correlation with the NAO index, which could reflect the limited range of this index in spring over the 2003-2008 period as well as AIRS's lack of sensitivity in the boundary layer.

AIRS CO columns over Alaska in April 2008 are anomalously low compared to other years, despite the anomalously high Russian biomass burning influence. We find that AIRS $\mathrm{CO}$ in this region is highly correlated with the Ocean Niño Index $(r=0.80)$. The low $\mathrm{CO}$ columns over Alaska in April 2008 were associated with La Niña conditions in fall 2007 through spring 2008 that weakened the Aleutian low pressure system. As a result, transport of Asian pollution to the Arctic was likely suppressed. We verified this result by comparing GEOS-Chem simulations for April 2005 (weak El Niño) and April 2008. This suggests that the impact of Asian pollution in the Arctic could be very large under strong El Niño conditions, so far missing from the AIRS record.

Acknowledgements. This work was supported by the NASA Tropospheric Chemistry Program and the NASA Atmospheric Composition Modeling and Analysis Program. The FTS measurements at Eureka were made as part of the Canadian Arctic ACE validation campaigns and by the Canadian Network for the Detection of Atmospheric Change, supported by the Canadian Foundation for Climate and Atmospheric Science, Canadian Foundation for Innovation, Canadian Space Agency, Environment Canada, Government of Canada International Polar Year funding, Ontario Research Fund, Natural Sciences and Engineering Research Council, Northern Scientific Training Program, Polar Continental Shelf Program, and the Atlantic, Nova Scotia and Ontario Innovation Trusts. WWM thanks the AIRS Project Office for support. JAF acknowledges support from a National Defense Science and Engineering Graduate Fellowship.

Edited by: P. Monks

\section{References}

Acker, J. G. and Leptoukh, G.: Online analysis enhances use of NASA earth science data, Eos Trans. AGU, 88(2), p. 14 and p. 17, 2007.

Andreae, M. O. and Merlet, P.: Emission of trace gases and aerosols from biomass burning, Global Biogeochem. Сy., 15, 955-966, 2001.

Barrie, L. A.: Arctic air pollution: An overview of current knowledge, Atmos. Environ., 20, 643-663, 1986.

Batchelor, R. L., Strong, K., Lindenmaier, R., Mittermeier, R. L., Fast, H., Drummond, J. R., and Fogal, P. F.: A new Bruker IFS 125HR FTIR spectrometer for the Polar Environment Atmospheric Research Laboratory at Eureka, Canada: measurements and comparison with the existing Bomem DA8 spectrometer, J. Atmos. Ocean. Tech., 26, 1328-1340, doi:10.1175/2009JTECHA1215.12009.

Bey, I., Jacob, D. J., Logan, J. A., and Yantosca, R. M.: Asian chemical outflow to the Pacific in spring: Origins, pathways, and budgets, J. Geophys. Res., 106, 23097-23113, 2001.

Bjerknes, J.: A possible response of the atmospheric Hadley circulation to equatorial anomalies of the ocean temperature, Tellus, 18, 820-829, 1966.

Carlson, T. N.: Speculations on the movement of polluted air to the Arctic, Atmos. Environ., 15, 1473-1477, 1981

Duncan, B. N., Martin, R. V., Staudt, A. C., Yevich, R., and Logan, J. A.: Interannual and seasonal variability of biomass burning emissions constrained by satellite observations, J. Geophys. Res., 108(D2), 4100, doi:10.1029/2002JD002378, 2003.

Duncan, B. N., and Bey, I.: A modeling study of the export pathways of pollution from Europe: Seasonal and interannual variations (1987-1997), J. Geophys. Res., 109, D08301, doi:10.1029/2003JD004079, 2004.

Duncan, B. N., Logan, J. A., Bey, I., Megretskaia, I. A., Yantosca, R. M., Novelli, P. C., Jones, N. B., and Rinsland, C. P. Global budget of CO, 1988-1997: Source estimates and validation with a global model, J. Geophys. Res., 112, D22301, doi:10.1029/2007JD008459, 2007.

Duncan, B. N. and Logan, J. A.: Model analysis of the factors regulating the trends and variability of carbon monoxide between 1988 and 1997, Atmos. Chem. Phys., 8, 7389-7403, 2008, http://www.atmos-chem-phys.net/8/7389/2008/.

Eckhardt, S., Stohl, A., Beirle, S., Spichtinger, N., James, P., Forster, C., Junker, C., Wagner, T., Platt, U., and Jennings, S. G.: The North Atlantic Oscillation controls air pollution transport to the Arctic, Atmos. Chem. Phys., 3, 1769-1778, 2003 http://www.atmos-chem-phys.net/3/1769/2003/.

Fortems-Cheiney, A., Chevallier, F., Pison, I., Bousquet, P., Carouge, C., Clerbaux, C., Coheur, P. F., George, M., Hurtmans, D., and Szopa, S.: On the capability of IASI measurements to inform about CO surface emissions, Atmos. Chem. Phys., 9, 87358743, 2009, http://www.atmos-chem-phys.net/9/8735/2009/.

Fuelberg, H. E., Harrigan, D. L., and Sessions, W.: A meteorological overview of the ARCTAS 2008 mission, Atmos. Chem. Phys., 10, 817-842, 2010, http://www.atmos-chem-phys.net/10/817/2010/.

Guenther, A., Karl, T., Harley, P., Wiedinmyer, C., Palmer, P. I., and Geron, C.: Estimates of global terrestrial isoprene emissions using MEGAN (Model of Emissions of Gases and Aerosols from Nature), Atmos. Chem. Phys., 6, 3181-3210, 2006, 
http://www.atmos-chem-phys.net/6/3181/2006/.

Heald, C. L., Jacob, D. J., Fiore, A. M., Emmons, L. K., Gille, J. C., Deeter, M. N., Warner, J., Edwards, D. P., Crawford, J. H., and Hamlin, A. J.: Asian outflow and trans-Pacific transport of carbon monoxide and ozone pollution: An integrated satellite, aircraft, and model perspective, J. Geophys. Res., 108(D24), 4804, doi:10.1029/2003JD003507, 2003a.

Heald, C. L., Jacob, D. J., Palmer, P. I., Evans, M. J., Sachse, G. W., Singh, H. B., and Blake, D. R.: Biomass burning emission inventory with daily resolution: Application to aircraft observations of Asian outflow, J. Geophys. Res.-Atmos., 108(D21), 8811, doi:10.1029/2002JD003082, 2003b.

Heald, C. L., Jacob, D. J., Jones, D. B. A., Palmer, P. I., Logan, J. A., Streets, D. G., Sachse, G. W., Gille, J. C., Hoffman, R. N., and Nehrkorn, T.: Comparative inverse analysis of satellite (MOPITT) and aircraft (TRACE-P) observations to estimate Asian sources of carbon monoxide, J. Geophys. Res., 109, D23306, doi:10.1029/2004JD005185, 2004.

Heald, C. L., Jacob, D. J., Park, R. J., Alexander, B., Fairlie, T. D., Yantosca, R. M., and Chu, D. A.: Transpacific transport of Asian anthropogenic aerosols and its impact on surface air quality in the United States, J. Geophys. Res., 111, D14310, doi:10.1029/2005JD006847, 2006.

Hegg, D. A., Warren, S. G., Grenfell, T. C., Doherty, S. J., Larson, T. V., and Clarke, A. D.: Source attribution of black carbon in arctic snow, Environ. Sci. Technol., 43, 4016-4021, doi:10.1021/es803623f, 2009.

Holloway, J. S., Jakoubek, R. O., Parrish, D. D., Gerbig, C., VolzThomas, A., Schmitgen, S., Fried, A., Wert, B., Henry, B., and Drummond, J. R.: Airborne intercomparison of vacuum ultraviolet fluorescence and tunable diode laser absorption measurements of tropospheric carbon monoxide, J. Geophys. Res.Atmos., 105(D19), 24251-24261, 2000.

Hudman, R. C., Jacob, D. J., Turquety, S., Leibensperger, E. M., Murray, L. T., Wu, S., Gilliland, A. B., Avery, M., Bertram, T. H., and Brune, W.: Surface and lightning sources of nitrogen oxides over the United States: Magnitudes, chemical evolution, and outflow, J. Geophys. Res.-Atmos., 112, D12S05, doi:10.1029/2006JD007912, 2007.

Hudman, R. C., Murray, L. T., Jacob, D. J., Millet, D. B., Turquety, S., Wu, S., Blake, D. R., Goldstein, A. H., Holloway, J., and Sachse, G. W.: Biogenic vs. anthropogenic sources of CO over the United States, Geophys. Res. Lett., 35, L04801, doi:10.1029/2007GL032393, 2008.

Hurrell, J. W., Kushnir, Y., Ottersen, G., and Visbeck, M.: An overview of the North Atlantic oscillation, in: The North Atlantic Oscillation: Climatic Significance and Environmental Impact, edited by: Hurrell, J. W., Kushnir, Y., Ottersen, G., and Visbeck, M., Geoph. Monog. Series, American Geophysical Union, 1-36, 2003.

Jacob, D. J., Crawford, J. H., Maring, H., Dibb, J. E., Clarke, A. D., Ferrare, R. A., Hostetler, C. A., Russell, P. B., Singh, H. B., Thompson, A. M., Shaw, G. E., McCauley, E., Pederson, J. R., and Fisher, J. A.: The ARCTAS aircraft mission: design and execution, Atmos. Chem. Phys. Discuss., 9, 17073-17123, 2009, http://www.atmos-chem-phys-discuss.net/9/17073/2009/.

Jaeglé, L., Jaffe, D. A., Price, H. U., Weiss-Penzias, P., Palmer, P. I., Evans, M. J., Jacob, D. J., and Bey, I.: Sources and budgets for $\mathrm{CO}$ and $\mathrm{O} 3$ in the northeastern Pacific during the spring of
2001: Results from the PHOBEA-II Experiment, J. Geophys. Res., 108(D20), 8802, doi:10.1029/2002JD003121, 2003.

Jaffe, D., Bertschi, I., Jaeglé, L., Novelli, P., Reid, J. S., Tanimoto, H., Vingarzan, R., and Westphal, D. L.: Long-range transport of Siberian biomass burning emissions and impact on surface ozone in western North America, Geophys. Res. Lett., 31, L16106, doi:0.1029/2004GL020093, 2004.

Kahn, R. A., Chen, Y., Nelson, D. L., Leung, F. Y., Li, Q., Diner, D. J., and Logan, J. A.: Wildfire smoke injection heights: Two perspectives from space, Geophys. Res. Lett., 35, L04809, doi:10.1029/2007GL032165, 2008.

Kiley, C. M., Fuelberg, H. E., Palmer, P. I., Allen, D. J., Carmichael, G. R., Jacob, D. J., Mari, C., Pierce, R. B., Pickering, K. E., and Tang, Y.: An intercomparison and evaluation of aircraft-derived and simulated $\mathrm{CO}$ from seven chemical transport models during the TRACE-P experiment, J. Geophys. Res.-Atmos., 108(D21), 8819, doi:10.1029/2002JD003089, 2003.

Klonecki, A., Hess, P., Emmons, L., Smith, L., Orlando, J., and Blake, D.: Seasonal changes in the transport of pollutants into the Arctic troposphere-model study, J. Geophys. Res., 108(D4), 8367, doi:10.1029/2002JD002199, 2003.

Koch, D., and Hansen, J.: Distant origins of Arctic black carbon: A Goddard Institute for Space Studies ModelE experiment, J. Geophys. Res., 110, D04204, doi:10.1029/2004JD005296, 2005.

Koike, M., Jones, N. B., Palmer, P. I., Matsui, H., Zhao, Y., Kondo, Y., Matsumi, Y., and Tanimoto, H.: Seasonal variation of carbon monoxide in northern Japan: Fourier transform IR measurements and source-labeled model calculations, J. Geophys. Res.-Atmos., 111, D15306, doi:10.1029/2005JD006643, 2006.

Kopacz, M., Jacob, D. J., Henze, D. K., Heald, C. L., Streets, D. G., and Zhang, Q.: Comparison of adjoint and analytical Bayesian inversion methods for constraining Asian sources of carbon monoxide using satellite (MOPITT) measurements of CO columns, J. Geophys. Res.-Atmos., 114, D04305, doi:10.1029/2007JD009264, 2009.

Kopacz, M., Jacob, D. J., Fisher, J. A., Logan, J. A., Zhang, L., Megretskaia, I. A., Yantosca, R. M., Singh, K., Henze, D. K., Burrows, J. P., Buchwitz, M., Khlystova, I., McMillan, W. W., Gille, J. C., Edwards, D. P., Eldering, A., Thouret, V., and Nedelec, P.: Global estimates of $\mathrm{CO}$ sources with high resolution by adjoint inversion of multiple satellite datasets (MOPITT, AIRS, SCIAMACHY, TES), Atmos. Chem. Phys., 10, 855-876, 2010, http://www.atmos-chem-phys.net/10/855/2010/.

Kuhns, H., Knipping, E. M., and Vukovich, J. M.: Development of a United States-Mexico Emissions Inventory for the Big Bend Regional Aerosol and Visibility Observational (BRAVO) Study, J. Air Waste Manag., 55, 677-692, 2005.

Labonne, M., Bréon, F.-M., and Chevallier, F.: Injection height of biomass burning aerosols as seen from a spaceborne lidar, Geophys. Res. Lett., 34, L11806, doi:10.1029/2007g1029311, 2007.

Law, K. S. and Stohl, A.: Arctic Air Pollution: Origins and Impacts, Science, 315, 1537, doi:10.1126/science.1137695 2007.

Li, Q., Jacob, D. J., Bey, I., Palmer, P. I., Duncan, B. N., Field, B. D., Martin, R. V., Fiore, A. M., Yantosca, R. M., and Parrish, D. D.: Transatlantic transport of pollution and its effects on surface ozone in Europe and North America, J. Geophys. Res.-Atmos., 107(D13), 4166, doi:10.1029/2001JD001422, 2002.

Liang, Q., Jaeglé, L., Jaffe, D. A., Weiss-Penzias, P., Heckman, A., and Snow, J. A.: Long-range transport of Asian pollution 
to the northeast Pacific: Seasonal variations and transport pathways of carbon monoxide, J. Geophys. Res., 109, D23S07, doi:10.1029/2003JD004402, 2004.

Liu, H., Jacob, D. J., Bey, I., Yantosca, R. M., Duncan, B. N., and Sachse, G. W.: Transport pathways for Asian pollution outflow over the Pacific: Interannual and seasonal variations, J. Geophys. Res., 108(D20), 8786, doi:10.1029/2002JD003102, 2003.

McConnell, J. R., Edwards, R., Kok, G. L., Flanner, M. G., Zender, C. S., Saltzman, E. S., Banta, J. R., Pasteris, D. R., Carter, M. M., and Kahl, J. D. W.: 20th-century industrial black carbon emissions altered arctic climate forcing, Science, 317, 1381, doi:10.1126/science.1144856 2007.

McMillan, W. W., Barnet, C., Strow, L., Chahine, M. T., McCourt, M. L., Warner, J. X., Novelli, P. C., Korontzi, S., Maddy, E. S., and Datta, S.: Daily global maps of carbon monoxide from NASA's Atmospheric Infrared Sounder, Geophys. Res. Lett., 32, L11801, doi:10.1029/2004GL021821, 2005.

McMillan, W. W., Warner, J. X., Comer, M. M., Maddy, E., Chu, A., Sparling, L., Eloranta, E., Hoff, R., Sachse, G., Barnet, C., Razenkov, I., and Wolf, W.: AIRS views transport from 12 to 22 July 2004 Alaskan/Canadian fires: Correlation of AIRS $\mathrm{CO}$ and MODIS AOD with forward trajectories and comparison of AIRS CO retrievals with DC-8 in situ measurements during INTEX-A/ICARTT, J. Geophys. Res., 113, D20301, doi:10.1029/2007jd009711, 2008.

McMillan, W. W., Evans, K., Barnet, C., Maddy, E., Sachse, G., and Diskin, G.: AIRS version 5 CO retrieval: algorithm description and validation, submitted to IEEE T. Geosci. Remote, 2009.

McMillan, W. W., Pierce, R. B., Sparling, L. C., Osterman, G., McCann, K., Fischer, M. L., Rappenglück, B., Newsom, R., Turner, D., Kittaka, C., Evans, K., Biraud, S., Lefer, B., Andrews, A., and Oltmans, S.: An observational and modeling strategy to investigate the impact of remote sources on local air quality: A Houston, Texas case study from the Second Texas Air Quality Study (TexAQS II), J. Geophys. Res., 115, D01301, doi:10.1029/2009JD011973, 2010.

Niebauer, H. J.: Effects of El Nino-Southern Oscillation and North Pacific weather patterns on interannual variability in the subarctic Bering Sea, J. Geophys. Res.-Oceans, 93, 5051-5068, 1988.

Olivier, J. G. J., Bloos, J. P. J., Berdowski, J. J. M., Visschedijk, A. J. H., and Bouwman, A. F.: A 1990 global emission inventory of anthropogenic sources of carbon monoxide on $1^{\circ} \times 1^{\circ}$ developed in the framework of EDGAR/GEIA, Chemosphere-Global Change Science, 1, 1-17, 1999.

Olivier, J. G. J., and Berdowski, J. J. M.: Global emission sources and sinks, in: The Climate System, edited by: Berdowski, J. J. M., Guicherit, R., and Heij, B. J., A. A. Balkema Publishers/Swets \& Zeitlinger Publishers, Lisse, The Netherlands, 3377, 2001.

Olsen, E. T., Fishbein, E., Lee, S.-Y., Manning, E., and McMillan, W. W.: AIRS/AMSU/HSB Version 5 Level 2 Product - Levels, Layers and Trapezoids, Jet Propulsion Laboratory, Pasadena, CA, USA, 2007.

Park, R. J., Jacob, D. J., Field, B. D., Yantosca, R. M., and Chin, M.: Natural and transboundary pollution influences on sulfate-nitrate-ammonium aerosols in the United States: Implications for policy, J. Geophys. Res., 109, D15204, doi:10.1029/2003JD004473, 2004.

Quinn, P. K., Shaw, G., Andrews, E., Dutton, E. G., Ruoho-
Airola, T., and Gong, S. L.: Arctic haze: current trends and knowledge gaps, Tellus B, 59, 99-114, doi:10.1111/j.16000889.2006.00238.x, 2007.

Quinn, P. K., Bates, T. S., Baum, E., Doubleday, N., Fiore, A. M., Flanner, M., Fridlind, A., Garrett, T. J., Koch, D., and Menon, S.: Short-lived pollutants in the Arctic: their climate impact and possible mitigation strategies, Atmos. Chem. Phys., 8, 1723-1735, 2008, http://www.atmos-chem-phys.net/8/1723/2008/.

Raatz, W. E. and Shaw, G. E.: Long-Range Tropospheric Transport of Pollution Aerosols into the Alaskan Arctic, J. Appl. Meteorol., 23, 1052-1064, 1984.

Rahn, K. A.: Relative importances of North America and Eurasia as sources of arctic aerosol, Atmos. Environ., 15, 1447-1455, 1981.

Rastigejev, Y., Park, R., Brenner, M. P., and Jacob, D. J.: Resolving intercontinental pollution plumes in global models of atmospheric transport, J. Geophys. Res., 115, D02302, doi:10.1029/2009JD012568, 2010

Reid, J. S., Hyer, E. J., Prins, E. M., Westphal, D. L., Zhang, J., Wang, J., Christopher, S. A., Curtis, C. A., Schmidt, C. C., Eleuterio, D. P., Richardson, K. A., and Hoffman, J. P.: Global monitoring and forecasting of biomass-burning smoke: Description and lessons from the Fire Locating and Modeling of Burning Emissions (FLAMBE) program, IEEE J. Sel. Top. Appl., 2(3), 144-162, doi:10.1109/JSTARS.2009.2027443, 2009.

Rodionov, S. N., Overland, J. E., and Bond, N. A.: The Aleutian Low and Winter Climatic Conditions in the Bering Sea. Part I: Classification, J. Climate, 18, 160-177, 2005.

Sachse, G. W., Hill, G. F., Wade, L. O., and Perry, M. G.: Fastresponse, high-precision carbon monoxide sensor using a tunable diode laser absorption technique, J. Geophys. Res., 92, 20712081, 1987.

Shaw, G. E.: The Arctic haze phenomenon, B. Am. Meteorol. Soc., 76, 2403-2413, 1995.

Shindell, D. T., Faluvegi, G., Lacis, A., Hansen, J., Ruedy, R., and Aguilar, E.: Role of tropospheric ozone increases in 20th-century climate change, J. Geophys. Res., 111, D08302, doi:10.1029/2005JD006348, 2006a.

Shindell, D. T., Faluvegi, G., Stevenson, D. S., Krol, M. C., Emmons, L. K., Lamarque, J. F., Pétron, G., Dentener, F. J., Ellingsen, K., Schultz, M. G., Wild, O., Amann, M., Atherton, C. S., Bergmann, D. J., Bey, I., Butler, T., Cofala, J., Collins, W. J., Derwent, R. G., Doherty, R. M., Drevet, J., Eskes, H. J., Fiore, A. M., Gauss, M., Hauglustaine, D. A., Horowitz, L. W., Isaksen, I. S. A., Lawrence, M. G., Montanaro, V., Müller, J.-F., Pitari, G., Prather, M. J., Pyle, J. A., Rast, S., Rodriguez, J. M., Sanderson, M. G., Savage, N. H., Strahan, S. E., Sudo, K., Szopa, S., Unger, N., van Noije, T. P. C., and Zeng, G.: Multimodel simulations of carbon monoxide: Comparison with observations and projected near-future changes, J. Geophys. Res., 111, D19306, doi:10.1029/2006JD007100, 2006b.

Shindell, D. T., Chin, M., Dentener, F., Doherty, R. M., Faluvegi, G., Fiore, A. M., Hess, P., Koch, D. M., MacKenzie, I. A., Sanderson, M. G., Schultz, M. G., Schulz, M., Stevenson, D. S., Teich, H., Textor, C., Wild, O., Bergmann, D. J., Bey, I., Bian, H., Cuvelier, C., Duncan, B. N., Folberth, G., Horowitz, L. W., Jonson, J., Kaminski, J. W., Marmer, E., Park, R., Pringle, K. J., Schroeder, S., Szopa, S., Takemura, T., Zeng, G., Keating, T. J., and Zuber, A.: A multi-model assessment of pollution transport to the Arctic, Atmos. Chem. Phys., 8, 5353-5372, 2008, 
http://www.atmos-chem-phys.net/8/5353/2008/.

Shindell, D. T. and Faluvegi, G.: Climate response to regional radiative forcing during the twentieth century, Nature Geosci, 2, 294-300, 2009.

Staudt, A. C., Jacob, D. J., Logan, J. A., Bachiochi, D., Krishnamurti, T. N., and Sachse, G. W.: Continental sources, transoceanic transport, and interhemispheric exchange of carbon monoxide over the Pacific, J. Geophys. Res., 106(D23), 3257132590, 2001.

Stohl, A.: Characteristics of atmospheric transport into the Arctic troposphere, J. Geophys. Res., 111, D11306, doi:10.1029/2005JD006888, 2006.

Stohl, A., Berg, T., Burkhart, J. F., Fjæraa, A. M., Forster, C., Herber, A., Hov, Ø., Lunder, C., McMillan, W. W., and Oltmans, S.: Arctic smoke-record high air pollution levels in the European Arctic due to agricultural fires in Eastern Europe, Atmos. Chem. Phys., 7, 511-534, 2007, http://www.atmos-chem-phys.net/7/511/2007/.

Streets, D. G., Zhang, Q., Wang, L., He, K., Hao, J., Wu, Y., Tang, Y., and Carmichael, G. R.: Revisiting China's CO emissions after the Transport and Chemical Evolution over the Pacific (TRACE-P) mission: Synthesis of inventories, atmospheric modeling, and observations, J. Geophys. Res., 111, D14306, doi:10.1029/2006JD007118, 2006.

Susskind, J., Barnet, C. D., Blaisdell, J. M., Center, G. S. F., and Greenbelt, M. D.: Retrieval of atmospheric and surface parameters from AIRS/AMSU/HSB data in the presence of clouds, IEEE T. Geosci. Remote, 41, 390-409, doi:10.1109/TGRS.2002.808236, 2003.

Szopa, S., Hauglustaine, D. A., and Ciais, P.: Relative contributions of biomass burning emissions and atmospheric transport to carbon monoxide interannual variability, Geophys. Res. Lett., 34, L18810, doi:10.1029/2007g1030231, 2007.

Tanimoto, H., Sawa, Y., Yonemura, S., Yumimoto, K., Matsueda, H., Uno, I., Hayasaka, T., Mukai, H., Tohjima, Y., and Tsuboi, $\mathrm{K}$ : Diagnosing recent $\mathrm{CO}$ emissions and ozone evolution in East Asia using coordinated surface observations, adjoint inverse modeling, and MOPITT satellite data, Atmos. Chem. Phys., 8, 3867-3880, 2008,

http://www.atmos-chem-phys.net/8/3867/2008/.

Turquety, S., Clerbaux, C., Law, K., Coheur, P. F., Cozic, A., Szopa, S., Hauglustaine, D. A., Hadji-Lazaro, J., Gloudemans, A. M. S., Schrijver, H., Boone, C. D., Bernath, P. F., and Edwards, D. P.: $\mathrm{CO}$ emission and export from Asia: an analysis combining complementary satellite measurements (MOPITT, SCIAMACHY and ACE-FTS) with global modeling, Atmos. Chem. Phys., 8, 5187-5204, 2008, http://www.atmos-chem-phys.net/8/5187/2008/.

Val Martin, M., Logan, J. A., Kahn, R., Leung, F.-Y., Nelson, D., and Diner, D.: Smoke injection heights from fires in North America: Analysis of 5 years of satellite observations, Atmos. Chem. Phys. Discuss., 9, 20515-20566, 2009, http://www.atmos-chem-phys-discuss.net/9/20515/2009/.
Vestreng, V. and Klein, H.: Emission data reported to UNECE/EMEP: quality assurance and trend analysis \& presentation of WebDab, Norwegian Meteorological Institute, Oslo, Norway, MSC-W Status Report EMEP/MSC-W Note 1/02, 2002.

Warneke, C., Bahreini, R., Brioude, J., Brock, C. A., de Gouw, J. A., Fahey, D. W., Froyd, K. D., Holloway, J. S., Middlebrook, A., Miller, L., Montzka, S., Murphy, D. M., Peischl, J., Ryerson, T. B., Schwarz, J. P., Spackman, J. R., and Veres, P.: Biomass burning in Siberia and Kazakhstan as the main source for Arctic Haze over the Alaskan Arctic in April 2008, Geophys. Res. Lett., 36, L02813, doi:10.1029/2008GL036194, 2008.

Warner, J., Comer, M. M., Barnet, C. D., McMillan, W. W., Wolf, W., Maddy, E., and Sachse, G.: A comparison of satellite tropospheric carbon monoxide measurements from AIRS and MOPITT during INTEX-A, J. Geophys. Res., 112, D12S17, doi:10.1029/2006JD007925, 2007.

Yashiro, H., Sugawara, S., Sudo, K., Aoki, S., and Nakazawa, T.: Temporal and spatial variations of carbon monoxide over the western part of the Pacific Ocean, J. Geophys. Res., 114, D08305, doi:10.1029/2008jd010876, 2009.

Yurganov, L., McMillan, W. W., Grechko, E., and Dzhola, A.: Analysis of global and regional CO burdens measured from space between 2000 and 2009 and validated by ground-based solar tracking spectrometers, Atmos. Chem. Phys. Discuss., 9, 2847524911, 2009, http://www.atmos-chem-phys-discuss.net/9/28475/2009/.

Zhang, L., Jacob, D. J., Boersma, K. F., Jaffe, D. A., Olson, J. R., Bowman, K. W., Worden, J. R., Thompson, A. M., Avery, M. A., and Cohen, R. C.: Transpacific transport of ozone pollution and the effect of recent Asian emission increases on air quality in North America: an integrated analysis using satellite, aircraft, ozonesonde, and surface observations, Atmos. Chem. Phys, 8, 6117-6136, 2008.

Zhang, Q., Streets, D. G., He, K., Wang, Y., Richter, A., Burrows, J. P., Uno, I., Jang, C. J., Chen, D., and Yao, Z.: $\mathrm{NO}_{\mathrm{x}}$ emission trends for China, 1995-2004: The view from the ground and the view from space, J. Geophys. Res.-Atmos., 112, D22306, doi:10.1029/2007JD008684, 2007.

Zhang, Q., Streets, D. G., Carmichael, G. R., He, K. B., Huo, H., Kannari, A., Klimont, Z., Park, I. S., Reddy, S., Fu, J. S., Chen, D., Duan, L., Lei, Y., Wang, L. T., and Yao, Z. L.: Asian emissions in 2006 for the NASA INTEX-B mission, Atmos. Chem. Phys., 9, 5131-5153, 2009,

http://www.atmos-chem-phys.net/9/5131/2009/. 